University of the Pacific

Scholarly Commons

\title{
The Sounds of Silence: Waiting for Courts to Acknowledge That Public Policy Justifies Awarding Damages to Third-Party Claimants When Liability Insurers Deal With Them in Bad Faith
}

Francis J. Mootz III

Pacific McGeorge School of Law

Follow this and additional works at: https://scholarlycommons.pacific.edu/facultyarticles

Part of the Insurance Law Commons

\section{Recommended Citation}

Francis J. Mootz III, The Sounds of Silence: Waiting for Courts to Acknowledge That Public Policy Justifies Awarding Damages to Third-Party Claimants When Liability Insurers Deal With Them in Bad Faith, 2 Nev. L.J. 443.

This Article is brought to you for free and open access by the McGeorge School of Law Faculty Scholarship at Scholarly Commons. It has been accepted for inclusion in McGeorge School of Law Scholarly Articles by an authorized administrator of Scholarly Commons. For more information, please contact mgibney@pacific.edu. 


\section{The Sounds of Silence: \\ WAITING FOR COURTS TO \\ Acknowledge That Public Policy \\ Justifies Awarding Damages to ThIRD-Party Claimants When Liability Insurers DeAL With ThEM IN BAD FAITH}

\section{Francis J. Mootz III*}

My favorite insurance case has not been decided yet. In fact, the reported cases cast serious doubt on the possibility that it might be decided in the near future. There are only hints, asides, and dissenting opinions suggesting that liability insurers should be held accountable for dealing in bad faith with an injured third-party who has made a claim against the insured tortfeasor. There are a number of cases that contain conclusory doctrinal statements that no such liability exists, but there are very few cases that have directly considered the public policy question in clear and unambiguous terms. If a court ever considers this question squarely and decides that public policy justifies awarding damages to third-party claimants when liability insurers deal with them in bad faith, that case would certainly qualify as my favorite insurance law case. As of now, I am waiting patiently.

I don't intend to be difficult, but for purposes of this very interesting Symposium my favorite insurance "case" will be an amalgam of offbeat cases and dissenting opinions that point the way beyond the stultifying status quo. The majority of cases either defer this important question or decide the question on

* Professor of Law, Pennsylvania State University Dickinson School of Law. B.A. University of Notre Dame; A.M. (Philosophy) Duke University Graduate School, J.D. Duke University School of Law. I owe many thanks to Dean Peter Glenn for his enthusiastic support of this and other research projects, which were made possible by the award of a summer research stipend. I would also like to thank Andrew Tillapaugh, Class of 2002, for his dedicated research assistance and helpful conversations as I developed this topic, and to Carrie Leslie, Class of 2002, for research assistance in the final stage of the project. I received many helpful comments from colleagues when I presented this paper at a faculty colloquium, and I especially wanted to thank my colleague, Mike Navin, for his spirited critique of my thesis. Tom Baker provided some incisive comments, suggestions, and criticisms in an effort to strengthen my thesis, for which I am grateful. Floyd Wilson of McCary, Wilson, \& Pryor, P.C. in Albuquerque, New Mexico provided extensive comments "from the trenches" that I found very helpful. Most important, I am grateful to Jeff Stempel for his very helpful comments on a draft and for his kind invitation to join in this project and to have the honor of submitting these thoughts alongside the essays of a distinguished group of insurance law scholars and practitioners. 
technical or narrowly circumscribed doctrinal grounds that do not permit full consideration of the issue. Because the essay format of this Symposium does not permit me to provide a detailed doctrinal and policy analysis, I propose only to put the issue of insurers' duties to third-party claimants on the table. To facilitate discussion of this broad topic, I will focus on the manner in which the California courts have handled this question, culminating in the recent decision of the Court of Appeals in Krupnick v. Hartford Accident \& Indemnity Co. ${ }^{1}$ My modest goal in these few pages is to justify my choice of a case that does not yet exist as my "favorite" insurance law case. In the spirit of the Symposium, I conclude this essay with an appendix that offers an example of how my favorite insurance case might read, should it ever be written.

\section{Why Courts Should Hold That Public Policy Prohibits Insurers From Dealing With InJured Third-Party Claimants in BAD FAITH}

Imagine the Patsy family, pulling up to an intersection in their minivan on a Sunday morning trip to a favorite breakfast spot. The traffic signal is red and the car comes to a complete stop. The day is bright and clear. There is little traffic. Vision on the street is unobstructed. Without warning, a pickup truck driving thirty-five miles per hour slams into the back of the Patsy minivan, pushing it into the middle of the intersection where it is struck immediately by crossing traffic. All members of the Patsy family sustain serious injuries that require hospitalization. Ima Patsy is unable to work for two months. Ben A. Patsy is unable to work for six months. Both children are traumatized severely by the accident.

The negligent driver of the pickup truck has an insurance policy with Family Insurance Bureau (FIB), a national insurer. The Patsy family has very little in the way of insurance protection for health and disability risks, and they immediately begin to suffer financial distress as a result of the accident. After getting nowhere with FIB's claims department, the family retains a local attorney to sue FIB for their injuries. FIB initially contends that its investigation has shown that the brake lights on the Patsies' minivan did not work, that they had negligently remained stopped in the road even though the stoplight had just changed to green, and that the parents both had preexisting injuries that are not compensable. After two years of fruitless negotiations and delaying tactics in the civil lawsuit, discovery finally establishes that FIB's contentions have little or no basis in fact and that they contradict what its own insured has told them about the accident. Only at this point does FIB agree to pay a sharply discounted amount on the Patsies' claim, from which the Patsies' attorney will subtract her fee. Only later will the Patsies learn that FIB has been following a corporate policy designed to settle claims for less than market value.

The Patsy family is all too eager to accept the low settlement, because their lives are now in financial ruin. The mortgage company's patience has worn thin, and "repo man" has made several visits to their house. The settlement check arrives after deduction for court costs and their attorney's fee.

1 Krupnick v. Hartford Accident \& Indem. Co., 28 Cal. App. 4th 185 (1994). 
There is little sense of vindication. There is little sense of justice. There is only anger and a sense of betrayal. The Patsies' attorney files a complaint with the State Insurance Commissioner. Amazingly enough, the Commissioner investigates the matter and decides to sanction FIB for its behavior in this case and several others. This "victory" is against the bureaucratic odds, but nevertheless the Patsy family receives no compensation as a result of this administrative proceeding. They remain uncompensated victims of FIB's behavior.

The straightforward question posed by this hypothetical scenario is whether FIB should be held liable to the Patsy family for the harms caused by its claim settlement practices, even if such liability extends beyond the scope of coverage under its insured's automobile policy and outside the applicable limits of that coverage. The courts in this country generally have settled on a straightforward answer: "No." This response is unacceptable.

I begin with the premise that the great majority of insurers that offer thirdparty protection are reputable businesses that conduct their affairs honestly and fairly. But there are always cases, whether they represent the business strategy of a rogue insurer or an aberration in the otherwise legitimate claim handling process of a reputable insurer, in which an insurer's callous delay and stonewalling tactics cause substantial harm to innocent third-party claimants. There is no sound reason to insulate insurers from liability for causing additional injury to the injured claimants. There are only doctrinal "truths" that straightjacket courts from acknowledging what otherwise should be obvious principles of liability.

Insurers rightfully worry about insurance fraud, and they work hard to ensure that this destructive behavior is punished by force of law. The essence of insurance fraud is an attempt by a claimant to obtain more from the insurance contract than the claimant is entitled to receive. In this essay I will argue that the state should also aggressively police what I believe is aptly described as "reverse insurance fraud." I use the term "reverse insurance fraud" to describe a situation in which an insurer stonewalls payment to a third-party claimant in bad faith, which is to say solely for the purpose of minimizing its financial payments on the claim and without any legal justification relating to questions of liability or the measure of damages. Reverse insurance fraud is no less fraudulent than the usual cases of insurance fraud, because the insurer is attempting to secure unbargained-for benefits under the insurance contract with its insured. When an insurer seeks to retain funds that it contractually has promised to pay to an injured party without any good faith basis - which is to say, solely to benefit its own financial interests by browbeating the injured party into relinquishing part of a legitimate claim - then the integrity of the insurance contract is subject to a fraud no less than when a claimant makes false claims of soft tissue injury to increase the claimant's recovery. Fraudulent overreaching is fraudulent overreaching. Of course, it might be argued that it is more blameworthy for a large and sophisticated corporation to engage in such bad faith behavior, but simple parity in punishing fraud is an appropriate starting point.

The reasons for holding liability insurers accountable for bad faith actions that injure the third-party claimant should be obvious. First, an administrative proceeding devoted to regulating industry behavior in the aggregate is not well 
suited to preventing this behavior, since an insurer could selectively engage in this behavior without much fear of sanction. Moreover, avoiding future harms to the general public through administrative oversight does not correct the injuries already caused to individual third-party claimants. Finally, the public interest in preventing such harms might be much better protected through a system of liability to individual third-party claimants than by using the regulatory instrumentalities of the administrative state, since imposing the true costs of this behavior on the insurer would likely provide a stronger disincentive than the threat of administrative sanction.

Admittedly, the arguments against holding liability insurers accountable for bad faith settlement practices are equally obvious. First, these parties do not have a contractual relationship; rather, they essentially act as adversaries in negotiations and litigation. In this setting it is peculiar, to say the least, to talk of duties owed by the insurer to a claimant. Second, creating the potential for large verdicts against the insurer after the litigation against the insured has been resolved might lead to uneconomic decisions by the insurer to settle matters quickly, drawing into greater question the entire tort liability system and potentially increasing the cost of insurance. Finally, one might question how there can be "bad faith" when the insurance contract does not obligate the insurer to pay sums until such time as there is a settlement or a judgment against its insured.

The only means to resolve the competing arguments, of course, is to balance and mediate the competing considerations. It would be foolish for courts to adopt a "quasi-fiduciary" standard of behavior for liability insurers, given the adversarial context in which they deal with claimants. But it is equally foolish to impose no duty on liability insurers, given the enormous public interest in the tort-insurance system as an effective means of compensating injured parties. Given these competing considerations, it seems prudent to suggest that the courts should police bad faith behavior by insurers rather than attempting to articulate detailed affirmative duties of good behavior that insurers must follow when dealing with claimants. Case-by-case adjudications of bad faith behavior would permit claimants to recover for harm caused when an insurer attempts to retain benefits that the insured has contractually purchased to compensate the claimant.

I do not write on a clean slate. Before moving to a discussion of the state of the law after Krupnick, it is necessary to provide an historical overview of the context in which this question now arises. In Part Two of the essay, I review the traditional doctrinal rejection of any theory of liability and the subsequent movement by state courts to imply a private cause of action in favor of third-party claimants under statutory and regulatory schemes targeting unfair insurance practices. As adopted in California in Royal Globe ${ }^{2}$ this implied private cause of action appeared to address the question of insurer liability to third-party claimants directly. However, dissatisfaction with the Royal Globe approach led California to reverse course and refuse to grant rights to thirdparty claimants, bringing it back in line with the great majority of states. ${ }^{3}$ It

2 Royal Globe Ins. Co. v. Superior Court of Butte County, 592 P.2d 329 (Cal. 1979).

3 Thirty-one states have rejected the Royal Globe strategy of interpreting state unfair claims practices acts to provide an implied cause of action for third-party claimants. Eight states 
now is almost universally true that unfair claims practices statutes will not effectively provide third-party claimants with compensation if insurers deal with them in bad faith, absent an explicit provision.

After reviewing Royal Globe and its demise, I assess the current state of the law in Part Three. When overturning Royal Globe, the California Supreme Court acknowledged the possibility that a third-party claimant might have tort claims against an insurer for its unfair settlement and litigation practices. However, the courts have been unable to articulate a sound basis for developing this private law remedy for third-party claimants, owing largely to the fact that the historical attempt to imply private causes of action under a regulatory statute has skewed the analysis. In Part Four, I argue that courts must reconceptualize the public policy basis for holding that liability insurance carriers will incur tort liabilities if they deal with third-party claimants in bad faith. Once properly grounded, the public policy tort of engaging in bad faith settlement practices toward third-party claimants fits well into traditional doctrinal categories.

I conclude this essay with an Appendix, in which I suggest how a judicial opinion that endorses my approach might read. My goal is to persuade rather

expressly rejected the reasoning of the Royal Globe case. See White v. Unigard Mut. Ins. Co., 730 P.2d 1014, 1020-21 (Idaho 1986); Scroggins v. Allstate Ins. Co., 393 N.E.2d 718, 723-25 (Ill. App. 1979); Seeman v. Liberty Mut. Ins. Co., 322 N.W.2d 35, 40-43 (Iowa 1982); Earth Scientists v. U.S. Fid. \& Guar., 619 F. Supp. 1465, 1470-71 (D. Kan. 1985); Tweet v. Webster, 610 F. Supp. 104, 105 (D. Nev. 1985); Patterson v. Globe Am. Cas. Co., 685 P.2d 396, 397-98 (N.M. 1984); A\&E Supply Co. v. Nationwide Mut. Fire Ins. Co., 798 F.2d 669, 673-75 (4th Cir. 1986) (Virginia law); Kranzush v. Badger State Mut. Cas. Co., 307 N.W.2d 256, 269 (Wisc. 1981). Twenty-three states rejected the result reached in Royal Globe in the context of the particularities of their own statutory scheme. See Young v. Mich. Mut. Ins. Co., 362 N.W.2d 844, 846-47 (Mich. App. 1984); Morris v. Am. Family Mut. Ins. Co., 386 N.W.2d 233, 234-38 (Minn. Ct. App. Div. 1986); Lawton v. Great S.W. Fire Ins. Co., 392 A.2d 576, 581 (N.H. 1978); Pierzga v. Ohio Cas. Group, 504 A.2d 1200, 1204 (N.J. Super. 1986); Farmer's Union Cent Exch. v. Reliance Ins. Co., 675 F. Supp. 1534, 1536 (D.N.D. 1987); Strack v. Westfield Cos., 515 N.E.2d 1005, 1008 (Ohio Ct. App. 1986); Farris v. U.S. Fid. \& Guar. Co., 587 P.2d 1015, 1018-23 (Ore. 1978); D'Ambrosio v. $\mathrm{Pa}$. Nat. Mut. Cas. Ins. Co., 431 A.2d 966, 969-70 (Pa. 1981), superseded by statute on other grounds, 42 PA. Cons. Stat. $\$ 8371$ (1990); Swinton v. Chubb \& Son, Inc., 320 S.E.2d 495, 496-97 (S.C. 1984); Allstate Ins. Co. v. Watson, 876 S.W.2d 145, 146-49 (Tex. 1994); Wilder v. Aetna Life \& Cas. Ins. Co., 433 A.2d 309, 310 (Vt. 1981); Tank v. State Farm Fire \& Cas. Co., 686 P.2d 1127, 1132 (Wash. Ct. App. 1984), rev'd on other grounds, 715 P.2d 1133 (Wash. 1986); Herrig v. Herrig, 844 P.2d 487, 492 (Wyo. 1992).

Two states embraced the Royal Globe approach, but in both states the courts held that a third-party claimant must meet the statutory requirement of proving more than a single violation in order to recover. See Klaudt v. Flink, 658 P.2d 1065, 1068 (Mont. 1983); Jenkins v. J.C. Penney Cas. Ins. Co., 280 S.E.2d 252, 259-60 (W. Va. 1981), overruled on other grounds, State ex rel. State Farm Fire \& Cas. Co. v. Madden, 451 S.E.2d 721 (W. Va. 1994).

A district court interpreted Nevada's unfair claims practices act to provide an implied cause of action for insureds, but this interpretation relied heavily on the Nevada legislature's decision to grant express rights to insureds in an amendment to the act subsequent to the accrual of the cause of action. See Crystal Bay Gen. Improvement Dist. v. Aetna Cas. \& Sur. Co., 713 F. Supp. 1371, 1376-77 (D. Nev. 1989).

Finally, Kentucky permits a cause of action by third-party claimants for violations of the unfair claims practices act, but it finds the source of the cause of action in another statute that provides for a remedy for violations of any state statute that does not foreclose a civil remedy or provide its own civil remedy. See State Farm Mut. Auto. Ins. Co. v. Reeder, 763 S.W.2d 116, 117-18 (Ky. 1988). 
than to demonstrate. There is no doctrinal truth that is logically compelled; there is no "single right answer" that I brilliantly deduce. I claim only that my suggestion that liability insurers bear some measure of duty toward third-party claimants is a sound position that can be justified with traditional legal analysis. The courts have repeatedly shown that the opposite conclusion also can be justified with traditional legal analysis. The question is which analysis better accommodates contemporary understandings of the business of insurance, the public interests at stake, and the equities relating to the parties affected. My goal in writing a hypothetical judicial opinion is to persuade the reader to endorse my position.

\section{The Rise and Demise of Royal Globe: The Judicial Creation of an IMPlied Statutory Remedy for Bad Faith Settlement Practices}

\section{A. The Baseline Common Law Rule: Liability Carriers Owe No Duty to Injured Third-Party Claimants}

As a general rule, courts hold that liability carriers owe no duty to injured third-party claimants. The doctrinal analyses usually embrace two general themes. First, courts hold that a third-party claimant has no special relationship with the insurance carrier that gives rise to a duty of good faith and fair dealing. Second, courts hold that a third-party claimant has no contractual rights against a liability insurer, even when claiming rights as a third-party beneficiary. In both instances, the courts contrast the third-party claimant with the insured, who has a contractual relationship with the insurance carrier and also enjoys the protections of a judicially-created heightened duty of good faith and fair dealing.

Courts traditionally have found that liability insurance carriers do not owe a duty of good faith to third-party claimants, distinguishing the court-created rule that liability carriers owe a duty of good faith and fair dealing to their insured to resolve the dispute within the policy limits. In an older case, the Georgia Court of Appeals provided a classic statement of the rationale that established the baseline rule of the common law:

While an automobile liability insurance company may be held liable for damages to its insured for failing to adjust or compromise a claim covered by its policy of insurance, where the insurer is guilty of negligence or of fraud or bad faith in failing to adjust or compromise the claim to the injury of the insured . . . it does not follow that a person injured by the insured and who is not a party to the insurance contract may complain of the negligence or bad faith of the insurer towards its policyholder in failing to adjust or compromise a claim against such policyholder, for the duty of the insurance company to use ordinary care and good faith in the handling of a claim against its insured arises out of the relationship between the insurer and the insured created by the contract or policy of insurance, and there is no fiduciary relationship or privity of contract existing between the insurer and a person injured by one of its policyholders. $^{4}$

This rationale obviously protected insurers who played hardball with third-party claimants in the settlement process. Thus, in response to a plain-

${ }^{4}$ Francis v. Newton, 43 S.E.2d 282, 284 (Ga. Ct. App. 1947). 
tiff's suit alleging that a carrier stonewalled payments in a case of clear liability and documented damages simply because the claimant resided in Maine and the accident occurred in the insured's state of North Carolina (thereby imposing practical obstacles and inconveniences to bringing suit), the court found no basis for recovery.

That the defendant may have acted in a manner which may have brought into play plaintiff's economic circumstances as pressure upon plaintiff to settle for an amount less than plaintiff believed his case was really worth does not constitute duress in legal contemplation, either to vitiate the settlement which was made or create an independent cause of action for damages. ${ }^{5}$

Similarly, in response to a plaintiff's allegations that an insurance carrier was categorically denying claims involving soft tissue injury in cases where property damage was less than $\$ 1000$, irrespective of the merits of the individual case, the Arizona Court of Appeals recently held that the insurer simply had no duties to the claimant during the settlement and litigation process. ${ }^{6}$

Along with many courts, ${ }^{7}$ California has embraced the rule that there is no duty of good faith owed by liability insurers to third-party claimants. In Zahn v. Canadian Indemnity Co., a married couple injured in an auto accident alleged that the carrier improperly and unreasonably refused to settle the husband's claim unless his wife agreed to settle her claim against the insured simultaneously. ${ }^{8}$ The court rejected their attempts to claim protection under the cases establishing that insurance carriers owe an obligation of good faith and fair dealing in settlement negotiations to their insureds, holding that nowhere

in those cases is there any mention of a duty to the adversary in the litigation between the injured party and the insured to settle the former's claim against the latter. ... [The claimant has no] right to require the insurer to negotiate or settle with him prior to the establishment of the insured's liability ...9

The doctrinal starting point for analysis, then, is that an insurance carrier owes duties to its insured that may give rise to tort liability, but in the claim settlement and litigation process it owes no duties to the injured third party claimant. ${ }^{10}$

5 Linscott v. State Farm Mut. Auto. Ins. Co., 368 A.2d 1161, 1164 (Me. 1977).

6 Leal v. Allstate Ins. Co., 17 P.3d 95, 100 (Ariz. Ct. App. 2000).

7 See, e.g., Brown v. Candelora, 708 A.2d 104, 113 (Pa. Super. Ct. 1998) (extended string cite of jurisdictions rejecting third-party claimant rights); Dvorak v. Am. Family Mut. Ins. Co., 508 N.W.2d 329, 332 (N.D. 1993); Bowman v. Charter Gen. Agency, Inc., 799 S.W.2d 377, 380-81 (Tex. Ct. App. 1990); Liimatta v. Lukkari, 460 N.W.2d 251, 252 (Mich. Ct. App. 1990); Chavez v. Chenoweth, 553 P.2d 703 (N.M. Ct. App. 1976); Yelm v. Country Mut. Ins. Co., 259 N.E.2d 83, 84 (IIl. App. 1970).

8 Zahn v. Canadian Indem. Co., 129 Cal. Rptr. 286, 287 (Ct. App. 1976).

9 Id. at 288.

10 This rule is limited to the claim settlement and litigation period, however. Courts have recognized that when an injured third-party claimant obtains a verdict against an insured, and thereby triggers the insurance carrier's contractual duty to pay the damages on behalf of the insured, the claimant may maintain a direct action against the carrier for the policy proceeds. Therefore, in Zahn the court emphasized that no duty was owed until the contingency of establishing the insured's liability with a judgment was met. Id. at 288 . See also Hand v. Farmer's Ins. Exch., 29 Cal. Rptr. 2d 258, 264-67 (Ct. App. 1994) (holding that the claimant becomes a judgment creditor entitled to enforce the insurance contract as a third-party beneficiary and also subrogates to the insured's special relationship with the carrier, and distin- 
Courts justify this position by noting that an insurer's breach of the duty to its insured to settle a case does not injure the third-party claimant, but rather benefits that claimant by making additional funds available to satisfy the excess verdict. In the unanimous opinion in Murphy v. Allstate Insurance Co., the California Supreme Court spoke definitively on the issue:

Unlike a failure to investigate the representations of the insured, a breach of the duty to settle does not involve the risk that a person injured by a negligent motorist will fail to receive the compensation called for by that law. Breach of the duty to settle will, if anything, allow the injured party to recover the amount of the offered settlement, perhaps an additional sum to the extent of the policy limits, and sums in excess of those limits from the negligent motorist. Because an insurer's refusal to accept a reasonable settlement does not diminish the injured claimant's recovery, the policy of compensating persons injured by a negligent motorist is not frustrated. ${ }^{11}$

Courts repeatedly make the same point: the insurer's breach of its good faith settlement duties actually benefits the third-party claimant, and thus cannot give rise to direct tort liability to the claimant. ${ }^{12}$

Given the unavailability of tort liability for bad faith settlement practices, some claimants have premised their claims against insurers on contract principles. A third-party claimant obviously has no contract with the liability insurer, but claimants have argued that they should have the rights of third-party beneficiaries since the purpose of the insurance contract is for the carrier to make payments to the claimant. However, courts begin with the fact that an insurance contract is in the nature of an indemnity contract: the insurer has no obligation to pay sums to the claimant until such time as the insured becomes legally obligated to make such payments. Thus, in Zahn, the California Court of Appeals held that third-party beneficiary rights do not arise under a liability insurance contract until the insured's liability is established by an adverse judgment. ${ }^{13}$ Courts generally conclude that the insurance policy is intended to benefit only the insured and is not intended to benefit the claimant, at least until the insured suffers a judgment. ${ }^{14}$ Although the Florida Supreme Court unanimously reached the opposite conclusion in holding that a claimant could use

guishing this situation from the general rule that a liability carrier has no duties to a thirdparty claimant prior to judgment); D.H. Overmyer Telecasting Co., Inc. v. Am. Home Assurance Co., 502 N.E.2d 694, 700 (Ohio Ct. App. 1986) (Markus, P.J., concurring) (concluding that an injured party has no right in the insurance policy until such time as a verdict against the insured triggers the carrier's duty to indemnify, at which time the carrier may owe a duty of good faith to the injured third party).

11 Murphy v. Allstate Ins. Co., 132 Cal. Rptr. 424, 429 (1976).

12 Murray v. Mossman, 355 P.2d 985, 987 (Wash. 1960); Biasi v. Allstate Ins. Co., 249 A.2d 18, 20 (N.J. Super. Ct. App. Div. 1969); Yelm v. Country Mut. Ins. Co., 259 N.E.2d 83, 84 (Ill. App. Ct. 1970); Scroggins v. Allstate Ins. Co., 393 N.E.2d 718, 721 (Ill. App. Ct. 1979); Brown v. Candelora, 708 A.2d 104, 108 (Pa. Super. 1998). See generally Robert E. Keeton, Liability Insurance and Responsibility for Settlement, 67 HARV. L. REV, 1136, 1176 (1954) ("Not only is company without any duty to claimant to accept claimant's reasonable settlement offer, but also, if there is a sizable disparity between the settlement offer and the amount of the judgment obtained in the trial which follows refusal of the offer, claimant is benefited [sic] rather than harmed by company's refusal to settle.").

13 Zahn, 129 Cal. Rptr. at 288. See also Rowlands v. Phico Ins. Co., 2000 WL 1092134, at *5 (D. Del. July 27, 2000) (citing cases).

14 See, e.g., Page v. Allstate Ins. Co., 614 P.2d 339, 340 (Ariz. Ct. App. 1980); Chapell v. LaRosa, 2001 WL 58057, at*2-4 (Conn. Super. Jan. 5, 2001). 
third-party beneficiary principles to sue for the excess judgment after the insurer engaged in bad faith, ${ }^{15}$ this case appears to be an anomaly. ${ }^{16}$ The Florida Supreme Court later limited its holding dramatically by explaining that it utilized third-party beneficiary principles only to obviate the need for a claimant to receive an assignment of the insured's bad faith rights after judgment, and not in recognition of any obligations owed by the insurer directly to the third-party claimant. ${ }^{17}$

It is safe to conclude that an insurance carrier owes no duties to the claimant under third-party beneficiary contract principles prior to the claimant obtaining a judgment against the insured, nor does the carrier owe heightened duties of good faith and fair dealing to the claimant during the settlement and litigation process, except to the extent that the insured may assign its rights to the claimant in satisfaction of an excess verdict. Courts generally justify these doctrinal positions by noting that it would be curious to afford any rights to the claimant under tort or contract since the insurance carrier steps into the shoes of the insured as the adversary of the claimant. In the words of one court, "An insurer can hardly have a fiduciary relationship both with the insured and a claimant because the interests of the two are often conflicting." 18 Simply put, the "insurer has a fiduciary duty to the insured but an adversary relationship with the victim."19 In light of the conflict of interest between the insured and the claimant, one court stated that the insurer has the "right" to force the claimant to trial to prove his case, even if the plaintiff alleges that the insurer is offering only nominal settlements in order to capitalize on the practical difficulties that the claimant may face in bringing suit in a distinct venue. ${ }^{20}$ The claimant may obtain an assignment of the insured's common law rights against the insurance carrier, but the courts almost unanimously ${ }^{21}$ insist that the claimant cannot assert any such rights without an assignment. ${ }^{22}$ If an insured refuses to

15 Thompson v. Comm. Union Ins. Co., 250 So. 2d 259 (Fla. 1971).

16 See Herrig v. Herrig, 844 P.2d 487, 492 (Wyo. 1992) ("The third-party-beneficiary argument has been rejected by virtually every court to address the issue, and we join those courts today.") (citations omitted); Elmore v. State Farm Mut. Ins. Auto. Ins. Co., 504 S.E.2d 893, 901 (W. Va. 1998); Page v. Allstate Ins. Co., 614 P.2d 339, 340 (Ariz. Ct. App. 1980); Murray v. Allstate Ins. Co., 507 A.2d 247, 249-50 (N.J. Super. 1986); Biasi v. Allstate Ins. Co., 249 A.2d 18, 21 (N.J. Super. Ct. App. Div. 1969).

17 Fid. \& Cas. Co. of N.Y. v. Cope, 462 So. 2d 459, 461 (Fla. 1985) (emphasizing that it did not create a duty of good faith and fair dealing owed to a third-party claimant, but rather that the "basis for an action remained the damages of an insured from the bad faith action of the insurer which caused its insured to suffer a judgment for damages above his policy limits. Thompson merely allowed the third party to bring such an action in his own name without an assignment.").

18 O.K. Lumber Co., Inc. v. Providence Wash. Ins. Co., 759 P.2d 523, 526 (Alaska 1988).

19 Chapell, 2001 WL 58057, at *4 n.2 (quoting Long v. McAllister, 319 N.W.2d 256 (Iowa 1992)).

20 Linscott v. State Farm Mut. Auto. Ins. Co., 368 A.2d 1161, 1163-64 (Me. 1977).

21 As related above, Florida recognizes a claimant's right to assert the insured's rights against the carrier for bad faith settlement practices, even in the absence of an express assignment. See supra notes 15-17 and accompanying text.

22 Murphy v. Allstate Ins. Co., 132 Cal. Rptr. 424, 429 (1976). 
assign its rights or cannot be located by the claimant, the claimant is without a remedy. ${ }^{23}$

The striking thing about these common law decisions is that they rest on the desire of courts to maintain doctrinal consistency rather than to achieve public policy goals or to avoid harm. The typical court opinion rejects the idea of a duty owed by liability insurers to third-party claimants after cataloguing various legal theories and finding them all wanting. It is a rare case $e^{24}$ that suggests that there would be harmful consequences if the law recognized that an injured third-party claimant would have a direct claim against an insurance carrier that acted in bad faith toward that person during the claims process; the cases tend only to hold that the law does not recognize such a duty under traditional legal principles. A recent case, Campbell v. American International Group, Inc. ${ }^{25}$ underscores this important point. Two soldiers stationed in Germany were involved in an auto accident, but the claimant sued after they returned to the United States in the tortfeasor's home state of Oklahoma. Under applicable German law, the liability carrier could be sued directly as jointly liable for the claimant's injuries. The insurer objected, citing the wellrecognized policy in Oklahoma that a liability carrier owes no duties to the claimant until judgment is entered. However, the court concluded that this rule was doctrinal, rather than a matter of fundamental public policy, and therefore enforced the applicable German statute. ${ }^{26}$

23 See Murray v. Mossman, 355 P.2d 985, $988-89$ (Wash. 1960) ("The [claimants] are trying to enforce a chose-in-action for [the insured], which [the insured] does not believe exists or is unwilling to enforce"); Page v. Allstate Ins. Co., 614 P.2d 339, 340 (Ariz. Ct. App. 1980) (rejecting an exception to the general rule when the claimant uses reasonable efforts to locate the insured in order to obtain an assignment but is unsuccessful). See also Rowlands v. Phico Ins. Co., 2000 WL 1092134, at *5 (D. Del. July 27, 2000) ("Without an assignment, Rowlands has no standing to bring these claims."). In Brown v. Candelora, the court held that public policy precluded a direct action by the claimant because the insured would be deprived of its right to maintain an action against the insurer to make himself whole as to damages such as his own increased attorney's fees. 708 A.2d 104, 112-13 (Pa. Super. Ct. 1998). The dissenting judge challenged this rationale:

Requiring a formal assignment can completely frustrate the bad faith claim. If the insured never granted the assignment, the insurer could benefit from its bad faith actions. Similarly, an insurer could agree to settle a bad faith claim with its insured for substantially less than the verdict amount. This type of action could create a process which protects an insurer who engages in bad faith conduct. In short, I can perceive of no reason to require an express assignment . . . . In a garnishment proceeding, the injured party is only entitled to receive that portion of the "bad faith" damages necessary to satisfy the judgment. The insured is free to maintain an action for its damages, i.e., attorney fees, beyond the judgment sum.

Id. at 116 (Del Sole, dissenting).

24 I have found one case that makes this public policy claim, but it does so only in dicta and in a very conclusory manner. See Biasi v. Allstate Ins. Co., 249 A.2d 18, 21 (N.J. Super. Ct. 1969) (baldly asserting that "public policy does not mandate that the injured party in the accident should be deemed the intended beneficiary of the company's contractual duty to its policyholder to act in good faith regarding settlement"), reaffirmed in Murray v. Allstate Ins. Co., 507 A.2d 247, 250 (N.J. 1986).

25976 P.2d 1102 (Okla. Ct. App. 1999).

26 The court reasoned:

We have never before recognized the right of a plaintiff to bring a direct action against the insurer of an alleged tortfeasor absent statutory edict. Herein, the applicable German law seems just such a statutory edict. ... Therefore, we see nothing repugnant to Oklahoma law in recog- 
Although courts have concluded as a general matter that an insurer owes no common law obligations to the third-party claimant in the handling of the claim, there are specific scenarios that might give rise to liability on more narrow grounds. For example, an insurer might be found liable for making fraudulent statements to a claimant during the settlement process. In Chavez $v$. Chenoweth ${ }^{27}$ the claimant in an automobile negligence case alleged that the insurer admitted its insured's fault and advised her not to retain an attorney because they "would take care of all her damages and give her reasonable compensation for her injuries." The claimant sued when the insurer made no payments after she delayed for some time in retaining an attorney. The court noted that the claimant was not owed a generalized duty of good faith, but it concluded that she had sufficiently alleged fraud, as well as breach of an oral contract to pay the insurance benefits. ${ }^{28}$

Fraud cases generally do not work well for claimants, however, because the fact that they have finally retained an attorney and are pursuing their rights leads some courts to conclude that there was no reliance on the fraudulent statements. ${ }^{29}$ Moreover, in light of the "adversarial" nature of the relationship between the parties, courts appear willing to provide a great deal of leeway to insurers. In a recent case, after being rear-ended in an automobile accident, the claimant was advised that the insurer would deal with him fairly and therefore that he did not need an attorney, and he received a letter stating in detail that the insurer would treat the claimant like its own customer. ${ }^{30}$ In fact, the claimant alleged, the insurer offered a low-ball settlement offer as part of a preexisting systematic effort to reduce soft-tissue injury payouts. ${ }^{31}$ The court held that the pleadings did not support a theory that by its affirmative conduct the insurer assumed a duty that otherwise would not exist, concluding that:

Allstate's "Customer Service Pledge" did not promise a fair settlement nor did it promise to treat the Leals as insureds. It promised only to consider them as "customers" and to provide "quality customer service." ... Nowhere did Allstate promise to make a fair settlement or to give equal consideration to the Leal's interest, as the duty of good faith would require. ...

[T]he Leals did not give up control of the settlement of their claim nor of their freedom of action. Nothing in the Customer Service Pledge deprived them of any and all remedies against Allstate's insured or against Allstate itself if the insured assigned any bad faith claims he might have. Allstate did not even promise to pay the Leal's claim; it promised only to discuss fair payment. All of Allstate's promises together did not create [a] fiduciary-like relationship 32

nizing and enforcing Germany's "statutory edict" that automobile liability insurers are jointly and severally liable with tortfeasors and may be sued by injured parties.

Id. at 1107.

27 Chavez v. Chenoweth, 553 P.2d 703, 709 (N.M. Ct. App. 1976).

28 Id.

29 Linscott v. State Farm Mut. Auto. Ins. Co., 368 A.2d 1161, 1164-65 (Me. 1977); Dvorak

v. Am. Family Mut. Ins. Co., 508 N.W.2d 329, 332 (N.D. 1993).

${ }^{30}$ Leal v. Allstate Ins. Co., 17 P.3d 95, 96-97 (Ariz. Ct. App. 2000).

31 Id.

32 Id. at $98-99$. 
When considered against the backdrop of doctrinal analyses that characterize the insurance carrier and third-party claimant as adversaries, claims that the insurer engaged in fraud during the settlement process become all the more difficult to establish.

A third-party claimant challenged this same systematic practice of denying legitimate claims by alleging that the insurer abused the legal process. In an unreported case, an Arizona jury awarded $\$ 15,000$ compensatory damages to a claimant for the emotional distress caused by the insurer's hardball tactics in a minor-injury insurance claim. ${ }^{33}$ Although defense counsel claimed victory in light of the plaintiff's claim for $\$ 500,000$ compensatory damages and unspecified punitive damages, the case is reportedly the first instance of a liability insurer being found liable under this theory. If the case survives the expected appeal it will provide a means of challenging express corporate decisions to pursue a "scorched earth litigation strategy" in order to increase insurer profits. However, courts generally have dismissed cases alleging equally egregious facts, concluding that claimants are barred as a matter of law from suing liability carriers under a theory of "maliciously defending" the litigation. ${ }^{34}$ Given the narrow pleading and proof requirements for the tort of abuse of process and the baseline doctrinal rule regarding carrier liability to claimants, it is unlikely that this tort will serve as an effective general vehicle for policing insurer bad faith.

One final potential avenue of recovery is opened when the third-party claimant is insured by the same carrier that insures the tortfeasor. In this situation, claimants have argued that they have the requisite contractual relationship with the insurer to trigger a duty of good faith and fair dealing. However, courts have consistently held that the claimant can assert a claim only if the carrier has breached a duty owed to the claimant under the claimant's policy, and do not recognize any duty owed by the carrier under the tortfeasor's policy toward the insured simply because the insured has a separate policy with the same carrier. For example, an insurer was liable to a claimant wife who was a co-insured with her tortfeasor husband under an automobile policy when the insurer promised that it would provide her with all available funds under her policy, but did not advise her that she could sue her husband for damages under the liability portion of that policy. ${ }^{35}$ However, when a co-insured wife sues her tortfeasor husband for damages, the courts generally do not recognize any duties owed by the carrier to the claimant wife under the liability portion of the

33 See Rebecca Porter, Jury Punishes Allstate for "Scorched-Earth" Tactics, 37 Trial 70 (Dec. 2001); David Hechler, Allstate found liable for Abuse of Process, NAT'L LAw J., Oct. 22,2001 , at A15.

34 See Rowlands v. Phico Ins. Co., 2000 WL 1092134 (D. Del. July 27, 2000) and cited cases. In Rowlands, the medical malpractice plaintiff alleged that the liability carrier never notified the defendant doctor of the suit, nor secured his participation, and then only at the last minute before trial it disclaimed liability under the policy provision requiring the insured to cooperate in the defense of the action. $I d$. at $* 1$. The court concluded that Phico owed no contractual or tort duties to Rowland during the litigation, and that she was limited to rights she could obtain by assignment from the (still missing) defendant doctor. Id. at $* 5$.

${ }^{35}$ Dercoli v. Pa. Nat'l Mut. Ins. Co., 554 A.2d 906 (Pa. 1989). 
policy. ${ }^{36}$ The distinction between breach of a duty owed to a claimant in her insured capacity, versus finding that an insurer owes no duties to an insured in her capacity as a third-party claimant, is a consistent theme in the case law. ${ }^{37}$

The cases strongly suggest that there is no common law basis for imposing liability on liability carriers when they deal with third-party claimants in bad faith. In many respects, it is difficult to quarrel with these cases. There is good reason to reject a third-party beneficiary theory under general principles of contract law, and there is equally good reason to refuse to extend the heightened duty of good faith and fair dealing owed to an insured to a third-party claimant. The fact that there may also be good reason to change these doctrinal rules does not mean that there is a compelling argument against the traditional approach. Even if the common law rule requiring claimants to obtain an express assignment of rights before seeking to garnish the excess judgment in the hands of the carrier who has acted in bad faith toward its insured makes little sense when considering the real world contexts in which these claims arise ${ }^{38}$ this doctrinal point regarding the ability to assert the insured's rights is not directly pertinent to the question of a third-party claimant's right to proceed directly against an

36 Sperry v. Sperry, 990 P.2d 381, 383-84 (Utah 1999) (distinguishing the Dercoli case, supra note 3 ). In another case involving a similar set of facts, the court reasoned:

The relationship between the parties, and the duties arising from that relationship, must be considered in the context of the particular occurrence in dispute. . . Although Mrs. Rumley had a contractual relationship with Allstate, the claim underlying the allegations of bad faith in failing to promptly settle for policy limits is based not upon benefits payable to her under the policy, but upon her husband's tort liability to her for his negligence. Mr. Rumley and Mrs. Rumley are antagonists, not co-claimants.

Rumley v. Allstate Indem. Co., 924 S.W.2d 448, 450 (Tex. Ct. App. 1996).

37 See Chavez v. Chenoweth, 553 P.2d 703, 708-10 (N.M. Ct. App. 1976) (acknowledging a cognizable claim when the plaintiff and tortfeasor were both insured by State Farm, and the plaintiff alleges that State Farm delayed making medical payments under her policy "for the purpose of embarrassing and humiliating the Plaintiff and . . . to pressure her into making settlement of her claim without benefit of outside counsel," but rejecting the claim that State Farm had a duty to settle her third-party claim in good faith simply because they insured her as well). Compare Rawlings v. Apodaca, 726 P.2d 565 (Ariz. 1986) (breach of duty when claimant's fire insurer did not turn over a fire investigative report that it prepared in the course of the settlement of the first party claim that would have implicated a neighbor insured by the same carrier) with Winchell v. Aetna Life, 394 N.E.2d 1114, 1118 (Ind. Ct. App. 1979) (In response to the claimant's assertion that it was owed duties by Aetna because the insurance package provided through his employer was with Aetna, the court held that "[c]ommon sense indicates that such a leap in reasoning is imprudent. It stretches the concept of a fiduciary relationship too far to say that a fiduciary relationship established between an insurance company and its insured extends to a lawsuit by that insured against another person insured by the same insurance company") and Pixton v. State Farm Mut. Auto. Ins. Co., 809 P.2d 746, 749-50 (Utah Ct. App. 1991) ("In the case before us, Pixton has no relevant contractual relationship with State Farm.") (emphasis added).

38 For example, in cases in which the insured is likely to be wholly judgment proof and perhaps difficult to find, an insurer might act in bad faith to coerce a lower settlement knowing that its insured is unlikely ever to assert a claim or to assign a claim to the plaintiff. Consequently, I would endorse the reasoning in Judge Del Sole's dissenting opinion, as described in note 23 supra. Additionally, even if the tortfeasor can be located and has some assets at risk, the assumption that the claimant would pursue these personal assets in order to induce the reluctant insured to assign its rights to the claimant may be mistaken. $C f$. Tom Baker, Blood Money, New Money and the Moral Economy of Tort Law in Action, 35 LAw \& SOC'Y REv. 275 (2001). 
insurer for injuries caused to the claimant by the insurer's bad faith. As to the question of direct liability, the baseline approach of the common law has been a firm, unanimous, and continuing refusal to countenance liability. Moreover, this response is difficult to criticize in the terms in which the question is presented, even if there are plausible and strong arguments that the doctrinal constraints should be changed to address this problem.

\section{B. The Royal Globe Approach of Interpreting State Unfair Insurance Practice Statutes to Create an Implied Cause of Action in Favor of Injured Third-Party Claimants}

In 1979, the California Supreme Court took a bold step in the face of the common law rule that had been recognized by a unanimous decision of the court in Murphy just three years earlier. In Royal Globe Insurance Co. v. Superior Court, by a four to three vote the court interpreted the state's unfair claims practices act to provide a private cause of action for third-party claimants who are injured as a result of an insurer's violation of the act. ${ }^{39}$ The statute speaks directly to the problem of bad faith in the claims handling process, and acknowledges that claimants can be injured by this behavior as well as insureds. Under 1972 amendments to the California Insurance Code, liability insurers commit unfair or deceptive acts or practices in the business of insurance by

(h) Knowingly committing or performing with such frequency as to indicate a general business practice any of the following unfair claims settlement practices:

(1) Misrepresenting to claimants pertinent facts or insurance policy provisions relating to any coverages at issue.

(2) Failing to acknowledge and act reasonably promptly upon communications with respect to claims arising under insurance policies.

...

(5) Not attempting in good faith to effectuate prompt, fair, and equitable settlements of claims in which liability has become reasonable clear.

(12) Failing to settle claims promptly, where liability has become apparent, under one portion of the insurance policy coverage in order to influence settlements under other portions of the insurance policy coverage.

...

(14) Directly advising a claimant not to obtain the services of an attorney

(15) Misleading a claimant as to the applicable statute of limitations. ${ }^{40}$

Royal Globe held that this statutory scheme authorized private civil actions by third-party claimants when they are injured by conduct that constitutes a violation of the statute. ${ }^{41}$ The court distinguished Murphy by emphasizing that it was interpreting a statute rather than changing the established common law rule. ${ }^{42}$ However, working within the statutory scheme created difficulties because the statute was drafted to identify violations that would

39 Royal Globe Ins. Co. v. Superior Court of Butte County, 592 P.2d 329 (Cal. 1979).

40 Cal. Ins. Code $\$ 790.03(\mathrm{~h})$ (West 2001).

41 Royal Globe, 592 P.2d at 332-34. The court held that third-party claimants could bring a private cause of action because the statutory scheme clearly was designed to protect them as well as to protect insureds. Id. at 334-35.

42 Id. at 335. 
give rise to administrative sanctions. The court addressed this problem first by interpreting the prefatory language requiring a "frequency" of violations sufficient to establish a "general business practice" as being "ambiguous," and then held that these criteria only applied to actions initiated by the Insurance Commissioner, and not to actions for damages by individual insureds or third-party claimants. ${ }^{43}$

In dissent, Justice Richardson rejected the "labored attempt" to find a private cause of action in a statute clearly designed to identify acts that would be "subject to administrative regulation and discipline and then only if committed with the requisite frequency." understatement:

If, as the majority asserts, the Legislature had intended to change the course of California [common] law 180 degrees and thereafter to impose upon carriers civil liability to injured third persons for failing to settle claims against their insured, then surely much more direct and precise language would have been selected. ${ }^{45}$

In short, Royal Globe represented a sharply divided decision of the Supreme Court to imply within a regulatory statutory scheme a private cause of action that was firmly rejected under prior common law decisions.

Royal Globe engendered a legacy of confusion and complexity. ${ }^{46}$ For example, Royal Globe required third-party claimants to press their claims

$43 \mathrm{Id}$. at 336. Other courts found this leap to be too far from the plain intent of the statutory language. See, e.g., Dvorak v. Am. Family Mut. Ins. Co., 508 N.W.2d 329, 332-33 (N.D. 1993) (holding that, if a private right of action does exist, it would require the claimant to prove that the insurer is involved in prohibited conduct with such frequency as to indicate a general business practice); O.K. Lumber Co., Inc. v. Providence Wash. Ins. Co., 759 P.2d 523, 527 (Alaska 1988) ("The statute prohibits acts committed so frequently as to become a trade practice; it does not readily lend itself to enforcement by a private cause of action arising from a single claim.").

44 Royal Globe, 592 P.2d at 338-39 (Richardson, J., concurring in part and dissenting in part).

45 Id. at 340.

${ }^{46}$ In the Moradi-Shalal opinion overturning Royal Globe, the California Supreme Court reported that commentary

on Royal Globe has been generally critical of that decision. (See, e.g., Note, Rodriguez v. Fireman's Fund Insurance Companies, Inc.: An Illustration of the Problems Inherent in the Royal Globe Doctrine (1985) 15 Sw. U. L. Rev. 371; Note, Bad Faith: Defining Applicable Standards in the Aftermath of Royal Globe v. Superior Court (1983) 23 Santa Clara L. Rev. 917; Allen, Insurance Bad Faith Law: The Need for Legislative Intervention (1982) 13 PAC. L.J. 833, 843; Comment, Liability Insurers and Third-Party Claimants: The Limits of Duty (1981) 48 U. CHI. L. REv. 125, 148-51; Comment, Liability to Third Parties for Economic Injury: Privity as a Useful Animal, or a Blind Imitation of the Past, 12 Sw. U. L. Rev. 87, 111-18, 125-27 (1981); Price, Royal Globe Insurance Company v. Superior Court: Right to Direct Suit Against an Insurer by a Third Party Claimant, 31 Hastings L.J. 1161, 1176-87 (1980); Note, Extending the Liability of Insurers for Bad Faith Acts: Royal Globe Insurance Company v. Superior Court, 7 PePperdine L.Rev. 777, $791-93$ (1980)).

Moradi-Shalal v. Fireman's Fund Ins. Co., 758 P.2d 58, 64 (Cal. 1988). See also Elaine W. Reagan, Note, Moradi-Shalal v. Fireman's Fund: A Counter-Revolution in Insurance Bad Faith, 18 W. St. U. L. Rev. 847, 856-57 (1991) (noting that Royal Globe would promote multiple litigation, increase insurance costs, and create a conflict of interest between the insurer and the insured; in addition, Royal Globe created analytical difficulties such as what is "bad faith," when does the duty to settle arise, and when is the underlying action concluded). 
against the insured to conclusion before their cause of action against the carrier for unfair settlement practices would ripen. ${ }^{47}$ Subsequently, the Supreme Court resolved a split among the districts of the appellate court and determined that a third-party claimant must obtain a verdict against the insured to pursue a Royal Globe claim, holding that a settlement of the underlying action precludes a necessary prerequisite of a suit against the carrier. ${ }^{48}$ This doctrinal rule had perverse consequences, as exemplified in Williams $v$. Transport Indemnity $\mathrm{Co}^{49}$ In Williams, after the insured rear-ended the plaintiff, the carrier paid for property damage but allegedly refused to pay for the personal injuries because it knew that the claimant was dying of cancer and heart disease. The appellate court held that the failure of the claimant to bring suit prior to his death, even under these extreme circumstances, constituted a failure to satisfy a prerequisite of Royal Globe liability. ${ }^{50}$ As decisions like these cumulated, many parties began to question the desirability and effectiveness of the Royal Globe attempt to imply a private cause of action under a regulatory statute that seemed illsuited to damages actions by third-party claimants.

\section{The Demise of the Royal Globe Cause of Action: The California Supreme Court Retracts Its Questionable Statutory Interpretation}

Faced with an increasing number of complex issues and a rising chorus of criticism, in Moradi-Shalal v. Fireman's Fund Insurance Co., the California Supreme Court reversed Royal Globe and ruled prospectively that third-party claimants could no longer bring suit for violations of the unfair claims practices statute. $^{51}$ The court based its decision on the unpersuasive statutory interpretation" s2 supporting Royal Globe and the "undesirable social and economic effects" of the decision, including an increase in litigation and the cost of insurance. $^{53}$ By rejecting the strained statutory interpretation in Royal Globe, the Moradi-Shalal court referred the complex set of issues surrounding the rights of third-party claimants to the legislature for its express consideration.

It seems evident that resolution of these issues regarding the application of Royal Globe involves a difficult weighing of competing policies. Such a determination is more properly made by the Legislature. Yet the interpretive difficulties and complex

\footnotetext{
47 Royal Globe, 592 P.2d at 892.

48 Moradi-Shalal v. Fireman's Fund Ins. Co., 758 P.2d 58, 69 (Cal. 1988) (reversing Royal Globe prospectively, but determining for pending cases that settlement of the underlying action is insufficient to trigger liability).

49203 Cal. Rptr. 868 (Ct. App. 1984).

50 Id. at 873 .

51 Moradi-Shalal, 758 P.2d at 58. Insureds also lost their right to maintain a private civil action for violation of the unfair claims practices statute. See Zephyr Park, Ltd. v. Superior Court, 262 Cal. Rptr. 106 (Ct. App. 1989).

52 The court noted that the National Association of Insurance Commissioners subsequently had issued a report stating that the Model Unfair Claims Practices Act, on which California had modeled its statute, specifically excluded a private cause of action during the drafting process. Additionally, the court cited to additional legislative history confirming that the statute contemplated only administrative enforcement, and also noted substantial (but, ultimately, unsuccessful) efforts in the legislature to abrogate the Royal Globe holding. Id.

53 Id. at 65 . The court admitted that these undesirable effects were alleged by critics in the secondary literature, and were not proven by the parties in the litigation or supported by any empirical data before the court.
} 
public policy choices arising under Royal Globe result solely from its conclusion that the Legislature intended to confer a private right of action for violation of section 790.03. Reconsideration of that decision seems a far better alternative than allowing ourselves to be swept deeper into the developing interpretive whirlpool it has created. $^{54}$

On its face, then, the court did not discount the importance of recognizing the rights of third-party claimants. Instead, the court determined that it should await an express and detailed determination of these rights by the legislature rather than using questionable techniques of statutory interpretation to imply such rights as part of a regulatory scheme.

The court concluded by emphasizing that it did not intend to give insurance carriers free reign to treat third-party claimants unfairly. It encouraged the Insurance Commissioner to police unfair practices with administrative sanctions under the statute, and it emphasized that the Legislature always could create an express private right of action to replace the Royal Globe action. ${ }^{55}$ But the court went even further, adding:

Moreover, apart from administrative remedies, the courts retain jurisdiction to impose civil damages or other remedies against insurers in appropriate common law actions, based on such traditional theories as fraud, infliction of emotional distress, and (as to the insured) either breach of contract or breach of the implied covenant of good faith and fair dealing. Punitive damages may be available in actions not arising from contract, where fraud, oppression or malice is proved. In addition, prejudgment interest may be awarded where an insurer has attempted to avoid a prompt, fair settlement. $^{56}$

After eschewing the difficulties of elaborating the Royal Globe cause of action in the absence of more specific statutory authority, the court appeared to invite application of traditional common law principles to prevent unfair settlement practices that injure third-party claimants.

Such a concession was insufficient for Justice Mosk, the author of the Royal Globe opinion, who dissented vigorously. Caustically concluding that the court had "replaced Royal Globe with a 'Royal Bonanza' for insurance carriers, i.e. total immunity for unfair and deceptive practices committed on innocent claimants," and had "exalted principal over principle," Justice Mosk argued that administrative sanctions alone would be insufficient to protect third-party claimants from bad faith practices. ${ }^{57}$ Although his arguments in favor of holding insurers accountable to third-party claimants hold some appeal, Justice Mosk was unable to demonstrate that implying a cause of action under a regulatory statute was a prudent or effective means accomplishing this goal. In the end, the Royal Globe court's strained interpretation of the statutory scheme was probably unwarranted and ill-advised. Justice Mosk was unwilling to accept this fact, although he still could have insisted that this conclusion goes more to the means chosen by the Royal Globe court rather than the goal of holding insurers accountable for damages when they deal with third-party

54 Id. at 68 .

55 Id. at 69.

56 Id.

57 Id. at 75 (Mosk, J., dissenting). 
claimants in bad faith. Ironically, it was the majority opinion that pointed (even if only vaguely) in this direction.

\section{After Moradi-Shalal: In Search of a Theory of Liability for Bad Faith Settlement Practices by Insurers}

\section{A. Legislative Developments Following Moradi-Shalal}

Moradi-Shalal reversed the decision that the unfair claim practices act included an implied right of action for third-party claimants, but the court acknowledged the legislature's obvious power to create a private right of action expressly. Theoretically, the easiest method for overcoming the decision in Moradi-Shalal would be legislation establishing a private right of action, but the legislative process is a complex minefield not easily traversed. In his dissenting opinion in Moradi-Shalal, Justice Mosk noted that the well-funded insurance lobby had not been successful in its persistent efforts to secure legislation reversing Royal Globe during the nine years following the decision. ${ }^{58}$ After Moradi-Shalal, the shoe was on the other foot.

Despite the odds, in 1999 the California legislature enacted the Fair Insurance Responsibility Act of 2000 (FAIR). ${ }^{59}$ The Act was signed into law by Governor Davis on October 10, 1999, to become effective on January 1, 2000. FAIR survived the legislative process only because it was a compromise bill crafted with the assent of several large insurance carriers. ${ }^{60}$ FAIR did not fully restore Royal Globe, but it did provide for direct actions by third-party claimants in certain circumstances. The supporters of FAIR contended that the history following Moradi-Shalal demonstrated a pressing need to resuscitate the Royal Globe action in some form. The Consumer Attorneys of California (CAOC) pointed to the huge increase in profits and large drop in loss costs for auto insurers and general liability insurers following Moradi-Shalal, and insisted:

[I]nsurers have used their immunity under Moradi-Shalal to habitually delay settlement even when liability is clear, waiting until the day of trial in some cases, so that they may earn interest on the reserves maintained to settle claims and in turn force the claimant to accept a lower award if they needed an earlier settlement. CAOC asserts that the delay can be as long as three or four years, which forces many consumers to accept inadequate settlements when they cannot wait because of advanced age or serious injuries in need of medical attention. CAOC asserts that in some cases, the delay is so long that the consumer dies before any settlement, thereby letting the insurer off the hook for personal injury damages. ${ }^{61}$

In support of these claims, the Foundation for Taxpayer and Consumer Rights submitted a study demonstrating that the "average payout of a bodily injury

58 Id. at 68 (commenting that Royal Globe "has survived Herculean efforts of the insurance industry to legislatively overrule it").

591999 Cal. Stat. 720 et. seq. (S.B. 1237).

60 "The final compromise legislation was supported by the Consumer Attorneys of California, Mercury Insurance Group, and several commercial lines insurers including AIG, Travelers, and the American Insurance Association." Henry B. LaTorraca, Collision Course, 23 L.A. LAw. 50, 52 (Mar. 2000).

61 Senate Bill Analysis, S.B. 1237, Senate Judiciary Committee (May 26, 1999). 
claim in California in 1998 was $\$ 6,996$ compared to the national average payout of $\$ 9,540 . "$

FAIR did not survive long. The remaining industry opponents of the law gathered enough signatures to submit the new statute to the voters by referendum. ${ }^{62}$ Subsequently, FAIR was rejected by a margin slightly exceeding two to one. ${ }^{63}$ As might be expected, the sophisticated insurance lobby ran a wellfinanced campaign to defeat the Act, leading some newspaper editorial pages to charge that the insurers were engaging in deceptive tactics to avoid being held accountable for bad faith practices. ${ }^{64}$ Discerning a lesson in this tangled political storyline is difficult, to say the least. Although the legislature reacted favorably to the arguments by FAIR's proponents, it remains doubtful that there will be additional legislative action in light of the unsuccessful voter referendum. ${ }^{65}$

62 See CAl. Const. art. 2, $\$ 9(\mathrm{~b})$.

63 California Rejects Bad Faith Laws, 11 Ins. Acct. 11 (Mar. 13, 2000).

64 San Francisco Examiner, Mar. 6, 2000, at A17 ("Out of state insurance companies are spending \$50 million trying to defeat [FAIR]. Their front organizations say a "no" would save Californians from higher auto premiums. That is misleading drivel."); ThE PREss DEMOCRAT, Mar. 5, 2000, at G1 ("The worst example [of "hyperbole-if not bare-faced lying"] this [election] has been the campaign ads in opposition to [FAIR] . . . [Insurers have] raised more than $\$ 50$ million to make sure they win. All of this to defeat a state law designed to hold them accountable for following fair business practices"); The Press Democrat, Feb. 20,2000 , at G2 (decrying the fact that some insurers refused to work on the compromise bill and now "have dug in their heels and are trying to overturn these laws" with "deceptive advertising" and other "specious" tactics); L.A. TIMEs, Feb. 18, 2000, at B6 (arguing that insurers like State Farm, Allstate, and Fireman's Fund have conducted a "multimillion-dollar advertising blitz" in which "shreds of truth" are "hidden by the TV ads' brazen distortions"); L.A. Times, Jan. 12, 2000, at A3 (reporting that State Farm contributed $\$ 16.7$ million, and Farmers Insurance $\$ 15.8$ million toward a $\$ 44$ million war chest already accumulated months before the election to defeat FAIR).

65 In three states, the legislature responded to the judiciary's reluctance to imply a cause of action by expressly amending the insurance code to provide a private right of action in favor of third-party claimants. See MoNT. CODE ANN. \$ 33-18-242 (2001) (providing that insureds and third-party claimants may recover actual damages for a violation of certain provisions of the unfair claims practices act without having to prove that the violations were so frequent as to indicate a general business practice; but precluding common law actions alleging bad faith); N.M. STAT ANN. \$ 59A-16-30 (Michie 2001) (permitting any person injured by a violation to bring an action for actual damages, in addition to any available common law remedies); LA. REv. STAT ANN $\$ 22: 1220$ (West 2001) (providing a cause of action for certain defined bad faith actions in settling third-party claims). My argument that courts should provide tort remedies to third-parties claimants in certain circumstances obviously is superfluous as to jurisdictions that have expressly granted these rights to third-party claimants.

However, some state legislatures have amended their codes to provide an express cause of action only for insureds. See, e.g., NEv. REv. STAT. § 686A.310(2) (2001) (establishing cause of action for insureds); Gunny v. Allstate Ins. Co., 830 P.2d 1335, 1336 (Nev. 1992) (holding that the statutory cause of action is limited to insureds and is not available to thirdparty claimants). Consequently, the question of the rights of third-party claimants remains unanswered in the statute and is left to common law development.

A number of states have amended their insurance codes in a variety of ways to provide that there is no express private cause of action under the unfair claims practices act, leaving open the question of the extent to which injured parties can recover under common law theories. Some states parallel the holding of Moradi-Shalal by stating that the unfair claims practices act has no effect on whatever rights a claimant might otherwise have under common law. See Mo. Code AnN., INs. § 27-301(b)(2) (2001) ("This subtitle does not provide 
The Moradi-Shalal court eliminated the Royal Globe cause of action for damages, but it appeared to leave open the question whether courts could use violations of the insurance statutes as the basis for other remedies. This ambiguity led the appellate court to conclude that an insured person could use a violation of the state insurance statutes as the basis of a defensive estoppel. In Spray, Gould \& Bowers v. Ass'n International Insurance Co. ${ }^{66}$ the court held that an insurer's direct violation of an administrative regulation requiring notice of time limits pertaining to a claim provides the basis for an estoppel when the insurer later asserts a contract limitation defense. The court distinguished

or prohibit a private cause of action to, or on behalf of, a claimant or other person in any state."). This clearly leaves courts free to develop common law remedies for aggrieved parties.

Many states have amended their statutes to state clearly that there is no private right of action under the unfair claims practices act. See, e.g., Alaska Stat. § 21.36.125(b) (Michie 2001) ("The provisions of this section do not create or imply a private cause of action for a violation of this section."); ARIz. REv. STAT. \& 20-461(D) (2001) ("Nothing contained in this section is intended to provide any private right or cause of action to or on behalf of any insured or uninsured resident or nonresident of this state. It is, however, the specific intent of this section to provide solely an administrative remedy to the director for any violation of this section or rule related thereto."); GA CODE ANN. § 33-6-37 (2001) ("Nothing contained in this article shall be construed to create or imply a private cause of action for a violation of this article."); Me. Rev. STat. AnN. tit. 24-A, \& 2164-D(8) (West 2001) ("This section may not be construed to create or imply a private cause of action for a violation of this section."); TENN. CODE ANN. § 56-8-104(8) (2001) ("a private right of action shall not be maintained under this subdivision ...."). Other states make it clear that actions under the statute may be initiated only by the insurance commissioner. See, e.g., Haw. Rev. STat. § 431:13-107 (2001) ("All remedies, penalties and proceedings set forth in this article are to be invoked solely and exclusively by the commissioner."). Some states provide only that injured parties may file complaints with the commissioner. See, e.g., IND. CODE § 27-4-1-5.6(a) (2001) ("A person who believes the person has been adversely affected by an unfair claim settlement practice" may make written application to the superintendent for a hearing to determine if there has been a violation).

These provisions plainly are limited to removing any doubt about the intent of the legislature to create a private cause of action under unfair claims practices acts, but they do not purport to divest the courts of their common law power to recognize new causes of action in this area. To my knowledge, no state legislature has amended its insurance code to specifically insulate liability insurance carriers from common law theories of recovery.

Finally, some state legislatures have considered adding an express private cause of action to their unfair claims practices act, but have declined to do so, leading courts to interpret this as a legislative decision to preclude private rights of action. See, e.g., Allstate Ins. Co. v. Watson, 876 S.W.2d 145, 149 (Tex. 1994). In Watson, the court noted that in 1991, "the legislature deleted a provision from H.B.2 that would have provided a private cause of action ... to any "claimant' for unfair claim settlement practices," and concluded:

[W] cannot ignore the legislature's refusal to create a statutory private cause of action for unfair claim settlement practices for third party claimants [and therefore] we will not construe [the statutory cause of action for unfair competition and unfair business practices] to permit, indirectly, a third party claimant to sue an insurer for unfair claim settlement practices . . where she may not do so directly and where the legislature has specifically refused to create such a cause of action.

Id. Although legislative inaction typically is unreliable guidance for interpreting a previously enacted statute, it seems plausible that, when faced with similar circumstances, courts may choose not to ground liability in the state unfair claim settlement practices act.

6684 Cal. Rptr. 2d 552 (Ct. App. 1999), rev. denied, 1999 Cal. LEXIS 5359 (Aug. 11, 1999). 
Moradi-Shalal and concluded that estoppel is precisely the kind of non-damages remedy that Moradi-Shalal contemplated. ${ }^{67}$ The Spray court acknowledged that its decision might change the practices of some insurers, but concluded that

those insurers have no legitimate grounds for complaint. We create no new liability for insurers. . . The commissioner's regulations establish the standard of conduct for insurers in California. Insurers who flout the regulations have no right to gain a competitive edge on insurers who scrupulously follow the regulations and faithfully discharge their obligations to their insureds. ${ }^{68}$

Although distinguishable from implying a private cause of action under the unfair claims practices act, this analysis comes close to repeating the basis for the Royal Globe decision. If an insurer violates a statutory duty, and if that violation injures a third-party claimant who will not otherwise be compensated for the injury, it makes perfect sense to permit the injured party to seek redress on the basis of this breach of a statutory duty. Of course, the estoppel remedy only benefits insureds; third-party claimants who suffer injury as a result of violations of the insurance code do not gain anything from an estoppel remedy.

In a related vein, a federal district court in California held that an insured can bring a private action under California's Unfair Competition Act for fraudulent behavior by an insurance company in adjusting a property claim despite the rejection of an implied cause of action under the unfair claims practices statutes. The court reasoned:

In sum, the Court finds that notwithstanding Moradi-Shalal, allegations of fraudulent and unfair business activity are sufficient to state a cause of action for relief under the UCA. Because such causes of action are independently actionable from [the unfair claims settlement practices act section] 790.03, the Court finds that Moradi-Shalal does not preclude them from stating a claim under the UCA. ${ }^{69}$

A Texas Court of Appeals similarly found that the case law rejecting a third-party private cause of action under the unfair claims settlement practices statute does not mean "that all statutory causes of actions by third-parties are . . . barred, albeit they are significantly narrowed." insurer liable to the third-party claimant under the Deceptive Trade Practices Act when it directed the claimant to bring the damaged vehicle to a certain shop and agreed to pay for the repairs, but then refused to make payment. ${ }^{71}$ Finally, the Massachusetts Supreme Judicial Court held that violations of the state's Unfair Claims Settlement Practices statute were sufficient to trigger liability under the state's Deceptive Trade Practices Act, and that third-party claimants have standing to sue insurers under the Deceptive Trade Practices Act. ${ }^{72}$ However, the legislative history of the Massachusetts Deceptive Trade Practices Act is somewhat unique, suggesting that other jurisdictions may not follow this indirect approach to grounding insurer liability to third-party claimants in statu-

67 Id. at 539.

68 Id. at 560-61. This reasoning was endorsed in Neufeld v. Balboa Insurance Co., 101 Cal.

Rptr. 2d 151, 154-55 (Ct. App. 2000).

${ }^{69}$ Diaz v. Allstate Ins. Group, 185 F.R.D. 581,595 (C.D. Cal. 1998).

70 Webb v. Int'l Trucking Co., Inc., 909 S.W.2d 220, 224 (Tex. App. 1995).

71 Id.

72 See Van Dyke v. St. Paul Fire \& Marine Ins. Co., 448 N.E.2d 357, 360-61 (Mass. 1983). 
tory language. ${ }^{73}$ In short, an independent violation of a statutory scheme that includes a private remedy might still provide some relief to third-party claimants against liability insurers.

\section{B. The Unsuccessful Return to Common Law Theories of Liability After Moradi-Shalal}

The California courts also have struggled with the suggestion in MoradiShalal that it might be appropriate in some circumstances for claimants to recover damages from insurers using traditional common law theories such as "infliction of emotional distress." and the Moradi-Shalal decision begins to control new filings, third-party claimants have begun to seek damages for bad faith settlement practices under the relatively new tort of negligent infliction of emotional distress, or under the more well-established but demanding tort of intentional infliction of emotional distress. Initially, courts were reluctant to resuscitate a Royal Globe cause of action by permitting parties to re-package their cause of action as a tort. In effect, the courts moved toward the conclusion that facts giving rise to liability under the Royal Globe doctrine are necessary but not sufficient to trigger liability for emotional distress claims. Thus, in response to suits by third-party claimants under tort theories of emotional distress when they could not meet the Royal Globe requirements for recovery, courts held that the duty of the insurance carrier arose from the unfair claim practices act, and so failure to meet the requirements of Royal Globe was deemed fatal to the emotional distress suit. ${ }^{75}$ On the other hand, mere violation of the unfair claims practices act was held to be insufficient to satisfy the conduct requirement of emotional distress claims, particularly the "outrageous" standard for intentional infliction of emotional distress. $^{76}$

73 The court explained that it originally held that a single violation of the Unfair Claim Settlement Practices Act gave rise to a cause of action by an insured under the Deceptive Trade Practices Act. Id. at 360 (discussing Dood v. Commercial Union Ins. Co., 365 N.E.2d 802 (Mass. 1977)). Subsequently, the Massachusetts legislature amended the Deceptive Trade Practices Act to make clear that "any person" could maintain a private action, leading the court to conclude that third-party claimants are entitled to relief under the statute. Id. The court noted that one advantage to using the Deceptive Trade Practices Act is that the requirement of a pattern of violations under the Unfair Claims Settlement Practices Act would not apply to the private plaintiff. "We shall proceed on the assumption that a single act in the handling of a claim constitutes a violation of [the Deceptive Trade Practices Act] if it is an act that as part of a pattern of conduct would be a violation of [the Unfair Claim Settlement Practices Act]." Id. at 361 .

${ }^{74}$ Moradi-Shalal v. Fireman's Fund Ins. Co., 758 P.2d 58 (Cal. 1988).

75 Williams v. Transp. Indem. Co., 203 Cal. Rptr. 868, 873 (Ct. App. 1984) (failure to satisfy the Royal Globe prerequisites is fatal to claim for negligent infliction of emotional distress); Lee v. Travelers Cos., 252 Cal. Rptr. 468, 470 (Ct. App. 1988) (same).

${ }^{76}$ Schlauch v. Hartford Accident \& Indem. Co., 194 Cal. Rptr. 658, 664-65 (Ct. App. 1983) (violation of statute is insufficient to meet the requirement of outrageous conduct for intentional infliction of emotional distress despite more than a two year delay in paying the claim); Soto v. Royal Globe Ins. Co., 229 Cal. Rptr. 192, 198-200 (Ct. App. 1986) ("mere delay in payment of a worker's compensation award to an employee head of the household is not even remotely similar to the kind of abnormal event which will foreseeably trigger the high degree of trauma and distress" required for negligent infliction of emotional distress; similarly rejecting claim of intentional infliction of emotional distress); Lee v. Travelers 
Despite initial resistance, third-party claimants continued to argue forcefully that tort duties are independent of statutory duties, and that insurers should be held liable for their tortious behavior irrespective of whether the claimant has the right to bring a statutory action. With respect to intentional infliction of emotional distress claims, this argument has been accepted, although the claimant still bears the burden of proving that the insurer's behavior meets the required level of "outrageous" conduct. In Doctor's Co. Insurance Services $v$. Superior Court, ${ }^{77}$ a third-party claimant amended his Royal Globe complaint after Moradi-Shalal definitively established that his settlement for the policy limits prior to trial was fatal to pursuing his claim. The claimant, a victim of medical malpractice, re-pleaded her case to allege that the insurer intentionally inflicted emotional distress by hiding the insured doctor's admitted liability for three years in an effort to browbeat her into settling, going so far as to suborn perjured deposition testimony by the insured and another doctor. The court of appeals concluded that these facts trumped the court's traditional hesitancy to permit third-party claimants to pursue emotional distress claims against insurers:

Lee v. Travelers Companies held a plaintiff cannot avoid Moradi-Shalal by relabeling the theory, where the material allegations assert nothing more than an insurer's violation of its statutory duties.

Nevertheless, as suggested in Lee, an action may lie if based on outrageous conduct beyond mere violation of the insurer's duties. Thus, for example, a cause of action for intentional infliction of emotional distress may lie where an insurer sends harassing or deceptive letters in an effort to induce a third party claimant to settle.

It thus appears the facts pleaded in the . . complaint avoid the MoradiShalal bar, because advising an insured to lie in a deposition may constitute intentional outrageous conduct going beyond mere violation of the insured's duties under the Insurance code and causing foreseeable injury to plaintiffs. ${ }^{78}$

This analysis is certainly correct, but the strict pleading and proof requirements for intentional infliction of emotional distress suggest that this avenue of recovery will be reserved only for the most egregious cases.

The recently expanded tort of negligent infliction of emotional distress provides more opportunities for third-party claimants to recover for bad faith settlement practices, but the courts have not moved to embrace this theory of recovery under the Moradi-Shalal exception. It should not be surprising that courts are hesitant to apply the tort of negligent infliction of emotional distress to this context. First, the recent expansion of negligent infliction of emotional

Cos., 252 Cal. Rptr. 468, 470 (Ct. App. 1988) (failure to allege with specificity acts beyond violation of the statute that are so extreme as to exceed all bounds of what usually is tolerated in a civilized community precludes claim for intentional infliction of emotional distress).

77275 Cal. Rptr. 674, 676 (Ct. App. 1990).

78 Id. at 678 (citations omitted). However, the court ultimately concluded that the absolute statutory litigation privilege protected the carrier from liability, even though it had suborned perjury, because its role in the litigation effectively made it a participant for purposes of the statutory protection. Id. at 683-84. 
distress claims to cases not involving physical injury ${ }^{79}$ has opened a potentially huge Pandora's box; consequently, courts have cautiously applied the tort in new settings. ${ }^{80}$ Moreover, the history of the Royal Globe cause of action undoubtedly has made courts especially skeptical about permitting plaintiffs to use a flexible tort concept to reinstate Royal Globe in different guise. In the wake of Moradi-Shalal, negligent infliction of emotional distress appeared to be the sole remaining avenue to address the problem of insurer bad faith toward third-party claimants in a significant and far-reaching manner. This anticipated development has failed to materialize thus far.

In 1994, the court of appeals erected a substantial roadblock to negligent infliction of emotional distress claims in Krupnick v. Hartford Accident \& Indemnity $\mathrm{Co}^{81}$ This case not only signaled that the "emotional distress" exception of Moradi-Shalal would not become a broad-based tool for policing bad faith, it made clear that this would not even be a viable tort theory for thirdparty claimants. Krupnick is a watershed case because it considered the public policy question of imposing liability on insurers against the baseline common law rule and the history of the Royal Globe cause of action. For third-party claimants, negligent infliction of emotional distress appeared to be the last plausible theory for supporting a claim for damages against insurers. Krupnick sought to put an end to such hopes, although it was a split decision and contained a lengthy dissent. ${ }^{82}$

79 See Molien v. Kaiser Found. Hosps., 616 P.2d 813 (Cal. 1980) (extending the ruling in Dillon v. Legg, 441 P.2d 912 (Cal. 1968) to permit recovery of damages for negligent infliction of emotional or mental distress that is unaccompanied by physical injury).

80 Consider the dynamic context of employment law. Many employees have begun to file claims for negligent infliction of emotional distress as the theories for recovering for wrongful termination have run out of steam. Where such claims are not precluded by the exclusivity of the Worker's Compensation statutes, courts have been extremely cautious about permitting claims for negligent infliction of emotional distress to undermine the traditional "at will" rule. See Parsons v. United Techs. Corp., 700 A.2d 655, 667 (Conn. 1997) ("The mere termination of employment, even where it is wrongful, is therefore not, by itself, enough to sustain a claim for negligent infliction of emotional distress."). See also Hanley v. Riverside Methodist Hosps., 603 N.E.2d 1126, 1133 (Ohio Ct. App. 1991) (rejecting application of the tort of negligent infliction of emotional distress to the employment context and continuing the traditional adherence to the "bystander rule").

8134 Cal. Rptr. 2d 39 (Ct. App. 1994).

82 At least one court has remained open to the idea that the common law could provide a remedy for insurer bad faith. Recently, a Connecticut trial court refused to recognize a general tort duty owed by insurance carriers to third-party claimants, but went on to state: "All of this, of course, would not bar in the appropriate case other tort theories of recovery such as fraud or the negligent or intentional infliction of emotional distress if the insurer's dealings with a third-party claimant warranted these other common law allegations." Chappell v. LaRosa, 2001 WL 58057, at *4 n.2 (Conn. Super. Ct. Jan. 5, 2001). After then rehearsing the Moradi-Shalal rationale for not implying a private cause of action under the unfair claims practices statute, and quoting that court's reference to the potential liability under fraud and emotional distress theories, the court acknowledged the potential for flexible tort concepts to police insurer bad faith.

This court agrees with [the observations in Moradi-Shalal that there may be common law grounds for liability - to put another perspective on the issue, if the factual allegations made here do not support an action in fraud or negligent or intentional infliction of emotional distress, why should the passage and existence of [a regulatory statute] create a remedy for the same underlying conduct. But beyond that, this does not mean the law must remain frozen; the common law, 
In Krupnick, the third-party claimants had been rear-ended by the insured, settled the case for $\$ 295,000$ prior to trial, and then brought a Royal Globe action "for their purely emotional distress." ${ }^{83}$ The claimants revised their complaint to allege negligent infliction of emotional distress after the MoradiShalal decision precluded Royal Globe actions when the underlying action had been settled, but the trial court entered summary judgment for the insurer. ${ }^{84}$ Justice McDaniel, writing for the court, characterized the claimants' theory as nothing more than an attempt to use tort principles to revive Royal Globe ${ }^{85}$ In response to the claimants' argument that Moradi-Shalal had specifically invited courts to retain their jurisdiction to prevent insurer overreaching by using traditional common law theories of liability such as infliction of emotional distress, the court emphatically rejected the idea that Moradi-Shalal recognized any duties owed by insurance carriers to third-party claimants. The court held that liability for negligent infliction of emotional distress "is not sanctioned by particular language contained in Moradi-Shalal. . . . In our view, upon closer scrutiny, this 'reassuring language' does not constitute a substantive holding; it only assures us, beyond the overruling of Royal Globe, that nothing has changed." 86 Of course, prior to the Royal Globe opinion, the baseline common law rule was that insurers owed no duties to third-party claimants.

The Krupnick court then analyzed why third-party claimants could not state a claim for negligent infliction of emotional distress against insurance carriers who handle their claims in bad faith. First, the court reasoned that numerous actions can foreseeably result in some other person experiencing some emotional distress, and therefore that tort liability must be grounded on a pre-existing duty of some kind, rather than simply on foreseeability analysis. ${ }^{87}$ The court extensively discussed the modern case law regarding negligent infliction of emotional distress and held that the cases established (implicitly, if not explicitly) that the tort would cast an overly broad net of liability if it was not

flexible as it is, can always consider accommodating new types of factual allegations under such traditional torts.

Id. at *9. It is precisely this openness to flexible adaptation that the Krupnick court rejected. Whether any appellate court will begin to develop common law theories in this manner remains to be seen, but the prospects do not appear favorable.

83 Krupnick, 34 Cal. Rptr. 2d at 39-40.

84 Id. at 40 . The claimants also sued for intentional infliction of emotional distress and pursuant to a general statutory provision establishing liability for negligence, but the court determined that these claims could "be readily disposed of under established precedents" and did not include analysis of these claims in its published opinion. Id.

85 In reality, this case, insofar as it involves a claim based on negligent infliction of emotional distress, amounts to a thinly disguised effort to persuade us, despite the overruling of Royal Globe, to include within the theories of common-law liability for negligence, a cause of action based upon precisely the same facts as were actionable under the Insurance Code pursuant to Royal Globe, before that case was overruled.

To countenance a common-law action by third parties directly against insurance companies would restore the precise evils [of Royal Globe].

Id. at 40,45 (emphasis in original).

86 Id. at 41.

87 Id. at $46-49$. 
confined to situations where the tortfeasor already owed duties to the plaintiff. ${ }^{88}$

The court then noted that no California court had ever imposed a duty on insurance carriers to negotiate in good faith for the benefit of third-party claimants; consequently, the court placed the burden on the claimants to demonstrate the existence of a duty that could ground their claim for negligent infliction of emotional distress. ${ }^{89}$ This led the court to the substantive point in question: whether the claimants had met their burden of demonstrating that public policy supported imposing a duty on liability insurance carriers regarding their dealings with third-party claimants. At this juncture, the court simply restated the baseline common law rule that the insurance carrier is contractually obligated only to the insured until such time as the insured suffers a verdict, and therefore insurance carriers are free to make settlement determinations in their own economic interest and without any duty to the claimants. Thus, the court concluded,

Plaintiffs' view of this case is wholly out of touch with the economic goals which give rise to contracts of insurance in the first place. Insurance companies exist to provide a critical financial indemnity for the risks of their insureds, not to salve the feelings of displeased third-party claimants. As an actuarial matter, there is no way to factor in the emotional distress of third-party claimants in trying to compute the premiums to be charged for the risks faced by the insured policy holders. ${ }^{90}$

Because liability insurers are free to refuse to settle claims for their own business interests and without regard for the interests of third-party claimants, the court concluded that there was no basis for finding a pre-existing duty between these parties that would support a claim for negligent infliction of emotional distress by third-party claimants. The following year, Justice McDaniel made clear that the import of Krupnick was to "reject out of hand" the claim that insurers owe any duty to third-party claimants: "The Krupnick decision is a complete answer to the argument of plaintiff's counsel that there was a direct duty owed plaintiff by defendant to investigate the claim and to offer policy limits once all the facts were disclosed. There is no such duty." 91

Justice Timlin dissented in the strongest terms, arguing that the court had misinterpreted both the claimant's theory of recovery and the applicable law. As to the legal requirements for stating a claim for negligent infliction of emotional distress, he rejected the requirement that tort liability be predicated on the breach of a duty that existed prior to the conduct in question. ${ }^{92}$ Moreover, because Moradi-Shalal clearly contemplated that courts would apply traditional

88 Id. at 49-53. The court was operating in a doctrinal area described by one commentator at that time as "a Gordian knot" due to the Supreme Court's lack of guidance, with the result that "mass confusion" was reigning among the lower courts. Colleen Wilcox Heidenreich, Comment, Clarifying California's Approach to Claims of Negligent Infliction of Emotional Distress, 30 U.S.F. L. REv. 277 (1995). Justice McDaniel, the author of the opinion in Krupnick, was building on an earlier opinion in which he had concluded that liability for negligent infliction of emotional distress had to be based on something more than foreseeability. See Bro v. Glaser, 27 Cal. Rptr. $2 d 894$ (Ct. App. 1994).

89 Krupnick, 34 Cal. Rptr. 2d at 49-50.

90 Id. at 50-51.

91 Messersmith v. Mid-Century Ins. Co., 43 Cal. Rptr. 2d 871, 879 (Ct. App. 1995).

92 Krupnick, 34 Cal. Rptr. 2d at 63-64 (Timlin, J., dissenting). 
tort principles to this relationship, Justice Timlin also argued that the majority erred by assuming that Moradi-Shalal had simply reaffirmed the baseline common law rule. ${ }^{93}$ He concluded that the claimants "are simply asking that this court apply the same principles of tort liability to automobile liability insurance companies in their relationship with claimants as are applied to other tortfeasors." 94 The burden of proof, then, should be on insurers to demonstrate why they should be excepted from general tort law. ${ }^{95}$

The majority also misconstrued the nature of the claimants' theory of recovery, according to Justice Timlin. The gravamen of the action was "affirmative misconduct" by the insurance company, including hiding the clear liability of its insured and stonewalling settlement negotiations for three years. ${ }^{96}$ The claimants do not assume that there is a duty owed by the carrier to settle any claim made against an insured, he emphasized, as that admittedly "would be a ridiculous position." 97 Instead, their claim rests on the true nature of the relationship between the parties that is obscured by the baseline common law rule:

Upon the involvement of an insured in an accident with a person who incurs injuries and/or property damage, resulting in that person making a claim against the insurer, a special relationship begins to exist between the claimant and the insurer at the time the claim is made creating a duty by the insurer and claimant to attempt to resolve the claim without unreasonable delay, in fairness and in good faith. This special relationship is not adversarial in nature but is one of openness, candor and understanding. It only becomes adversarial when one or both parties act unreasonably and unfairly toward the other during the attempt to settle, e.g., when there has been unreasonable delay or arbitrary refusal by the insurer to resolve the claim, particularly when the insured's liability for the accident and the claimant's injuries and losses are reasonably certain. ${ }^{98}$

Based on this description of the relationship of the parties, the obligation at issue is a straightforward "duty to deal honestly and in good faith during settlement negotiations with third-party claimants, and to attempt to come to a fair settlement within a reasonable amount of time after the insured's liability has become reasonably clear and the claimant's damages are reasonably ascertainable." 99

The baseline common law rule is no longer persuasive, Justice Timlin contended, because the older cases only rejected a duty of good faith grounded in contract and failed to appreciate that such a duty should be imposed for reasons of public policy. His argument begins by appealing to the self-evident nature of his conclusion.

93 Id. at 61-63.

94 Id. at 63.

95 Id. at 80. Justice Timlin argued that CAL. Crv. CODE $\$ 1714$ (Deering 2001), setting out the fundamental principle that all persons are responsible for injuries caused by negligent conduct, establishes a public policy in favor of holding parties responsible for injuries caused by their negligent acts unless they can point to a stronger public policy to the contrary. Id. at 72-74.

96 Id. at 56-57.

97 Id. at 63 n.9.

98 Id.

99 Id. at 65. 
It is rather obvious that by entering into policies of automobile collision liability insurance, insurers are voluntarily assuming a duty to the insured to exercise due care in handling claims by such insured under such policies, just as it is obvious that they are also entering into a potential relationship with yet-to-be-identified claimants who may be injured by their insureds, which potential relationship can and will ripen into a legally significant relationship once the insurer is notified that its insured has injured a particular claimant. ${ }^{100}$

However, Justice Timlin later listed a number of public policy reasons why insurers should not be insulated from general tort liability.

First, he contended that the emotional and financial injuries suffered by third-party claimants when insurers act in bad faith toward them are foreseeable consequences because claimants reasonably expect insurers to investigate and settle claims fairly. ${ }^{101}$ The "obvious" nature of the relationship between the parties that engenders these expectations follows from a particular legal and social context: automobile owners are required to obtain insurance in order to protect the public; automobile liability insurers are "a government-regulated, public service entity with . . . concomitant duties to the general public as well as to its insured"; the general public policy to compensate injured parties; and the specific sanctions against insurer bad faith toward claimants in the unfair claims practices statute. ${ }^{102}$ The injuries suffered by claimants if their losses are not compensated "promptly and in good faith" are foreseeable as well, since it follows that a person with physical injuries who is forced to endure financial distress might well suffer emotional distress. ${ }^{103}$

Additionally, Justice Timlin argued that public policy supports imposing liability in such cases because there is a reasonable degree of certainty that the plaintiffs actually suffered harm, and there is a "direct connection between those injuries and defendants' conduct." 104 Moreover, bad faith conduct by an insurer is morally blameworthy, as evidenced by the unfair claim practices act and general principles of business ethics. ${ }^{105}$ Finally, there is a strong public interest in preventing such behavior by insurers, and imposing liability would place no undue burdens on insurers beyond inducing appropriate behavior. ${ }^{106}$ He summarized:

Insurance companies are in the business of insuring against risks, and presumably set their rates accordingly. ... Allowing insurance companies to negligently refuse to pay, or delay paying, legitimate business obligations which were reasonably foreseeable after due consideration of the risks involved cannot be condoned (as does the majority) by characterizing third party actions against such insurers as an unwar-

100 Id.

101 Id. at 82 .

102 Id. at $82-83$. As to the expectation that the insurer owes duties to claimants, Justice Timlin later added:

It is clear, under our mandatory financial liability laws, as well as under California's Insurance Code, that insurers exist and are allowed to do business in California not only to provide their insureds with financial peace of mind, but to provide persons injured by their insureds with financial recompense for their injuries in a reasonable and good-faith manner.

Id. at 85 .

103 Id. at 83.

104 Id.

$105 I d$. at $84-85$.

$106 \mathrm{Id}$. at 85. 
ranted expansion of tort liability, or by denying that such claimants can ever be the direct victims of insurers' negligent acts.

Just as public policy mandates that parents undertake the support of their own children, that spouses undertake each other's support, that employers, regardless of fault, bear the cost, through worker's compensation insurance, of workrelated injuries to employees, that tortfeasors bear the cost of injuries they have caused to others by wrongful conduct or nonconduct - so that, at least in part, such burdens do not fall upon the general public - so too public policy mandates that insurance companies undertake the burden of fairly and timely settling those claims as alleged here, when the insured's liability is reasonably clear and the claimants' damages are reasonably ascertainable and which they have contracted to cover, for a price, rather than allowing such costs and expenses encompassed by the claimed damages to fall on the shoulders of the injured claimants, and, in some cases, on the doctors and hospitals whose bills will go unpaid, the welfare systems to whom the injured parties may be forced to turn, and ultimately on the taxpaying public. ${ }^{107}$

Justice Timlin argued against narrowing the tort of negligent infliction of emotional distress, and he insisted that the relationship between an insurer and third-party claimant is sufficient under these tort principles to provide relief to the claimants.

Despite the force of his argument that public policy supported holding insurers accountable to third-party claimants for bad faith settlement practices, Justice Timlin's analysis was constrained by the need to conceptualize the cause of action in terms of negligent infliction of emotional distress. His public policy analysis is secondary, in that it is intended only to support the application of a specific tort to this relationship. Although the court expressly rejected his weighing of various public policies in favor of the baseline common law rule, Justice McDaniel's opinion is more directed toward constraining the scope of the tort of negligent infliction of emotional distress. Because negligent infliction of emotional distress is unlikely to gain ascendency in the courts as a broad theory of liability, the Krupnick court probably was correct to find that it is a poor doctrinal vehicle for preventing insurer bad faith. This begs the question that has never been analyzed directly: does public policy justify awarding tort damages to third-party claimants when liability insurers deal with them in bad faith?

\section{What a Long Strange Trip It's Been: Overcoming History and Building the Case That Public Policy Justifies Holding Insurance Carriers Liable to Third Party Claimants}

Important considerations of public policy justify holding insurers liable when they refuse to settle third-party claims in bad faith. However, the doctrinal history regarding the potential liability of insurers to third-party claimants has masked the public interest and confused the issue. In this section, I suggest a way to place this doctrinal history into context and then to re-conceptualize 
the question of insurer liability in terms of the public interest. I propose a principled attribution of liability to insurers when their bad faith conduct implicates important public policies, as opposed to implicating only the personal interests of the claimant.

A recent case from West Virginia, Elmore v. State Farm Mutual Automotive Insurance Co. ${ }^{108}$ provides a succinct recapitulation of the doctrinal history in the preceding sections. An insured driver crossed the center line and collided with the claimant's car, killing the claimant's pregnant wife and unborn child, and injuring the claimant and his three-year old son. ${ }^{109}$ State Farm untruthfully told the claimant that he was receiving the maximum settlement possible because the carrier had to reserve some of the coverage to settle claims by occupants of the insured's vehicle. State Farm also advised him against hiring an attorney when he was presented with the release, telling the claimant that his recovery wouldn't increase and he would then just have to pay onethird of his recovery to an attorney. ${ }^{110}$ In fact, State Farm had an additional $\$ 42,500$ of coverage available to settle the claim, which it finally paid years later when claimant's under-insurance carrier determined that the liability coverage had not been exhausted. ${ }^{111}$ The claimant then sued State Farm, alleging that it had breached duties owed to the claimant under these circumstances, since his failure to exhaust the liability limits made recovery under his own policy impossible.

The court denied recovery under every theory advanced by the claimant, holding that State Farm was his adversary in litigation and therefore owed no duty of good faith analogous to the duty it owed to its insured, that State Farm could not be liable for breach of a fiduciary duty created by its affirmative statements while settling the case, and that the claimant was not the third-party intended beneficiary of the insurance contract. ${ }^{112}$ At the same time, the court acknowledged the force of the claimant's arguments in favor of liability.

In advancing his argument [in favor of finding a fiduciary relationship was created], the plaintiff places special emphasis on the relative positions of the two parties during the settlement negotiations, that is, his own emotional vulnerability immediately following the deaths of his wife and unborn child and a powerful and astute insurance company bent on furthering its own narrow interests.

In closing, we emphasize that if the plaintiff's allegations against State Farm are true, State Farm's actions toward the plaintiff are truly reprehensible. This court has a longstanding policy of encouraging compromise and settlement of disputed claims. This policy flows, in part, from the recognition that the prompt resolution of an insurance claim is usually of the utmost importance to a claimant as a means of righting a wrong, treating an injury, or repairing a loss, and hopeful restoring some normalcy and happiness to his life. Here, for example, the plaintiff faced staggering loss and yet was forced to grapple with two insurance companies over a period of years just to receive what was owed him. The equitable and efficient settlement of claims is only achieved when both parties conduct themselves honorably. This is especially true of insurance companies because they possess the preponderance of power in the settle-

\footnotetext{
108504 S.E.2d 893 (W. Va. 1998)

109 Id. at 894-95.

110 Id. at 895.

111 Id.

112 Id. at 894-901.
} 
ment process. As noted above, we have set forth the standard of conduct expected of insurers in their contractual relationships with insureds. Likewise, the Legislature has prescribed the proper standard for insurance companies toward all claimants, including third parties, in [the unfair claims practices act]. ${ }^{113}$

Although the claimant was entitled to bring suit under West Virginia's state unfair claims practices act, in this case the court regretfully agreed that the claimant's statutory action was time-barred. ${ }^{114}$ Despite the court's poignant description of the reasons for holding the insurer liable for its alleged conduct, the claimant was left without a remedy. This, of course, is now the reality facing third-party claimants in the vast majority of states that rejected or reversed the Royal Globe implied action.

It is time to re-conceptualize the justification for holding insurance carriers liable to third-party claimants for bad faith settlement practices. The ground for liability is the public interest in having liability insurance carriers deal with claims fairly and honestly. From the beginning, the courts have analyzed the question in terms of the personal rights of the claimants rather than directly analyzing the question from the perspective of the public interest. The courts have been correct to reject common law or statutory grounds for liability premised on duties owed to the claimant, but have failed to consider compensating the claimant for his injuries to the extent that the insurer's conduct violates public policy.

The heightened duty of good faith and fair dealing owed by carriers to their insureds has no application to third-party claimants. This duty protects against the insurer's abuse of its control over the litigation in a manner that amounts to gambling with the insured's money by risking a verdict in excess of policy limits. As the courts repeatedly have stated, the breach of this duty works to the advantage of the claimant because the insurer must pay the excess verdict. In the third-party context, bad faith has nothing to do with exposing the insured to an excess verdict; instead, bad faith is wrongfully delaying payment to the third party. Courts have been correct not to conflate these two very different types of bad faith conduct.

Similarly, it is a stretch to construe the claimant as a third-party beneficiary of the contract of insurance between the carrier and the insured. The insured does not purchase the insurance policy to provide a benefit to the claimant, but rather to protect herself from financial distress in the event that she becomes liable to a third party. It also is likely that the insured does not care when the claimant receives compensation, so long as the insured is insulated from the exposure caused by her negligence. Consequently, courts have been correct to reject the idea that bad faith settlement practices are precluded by the intent to make the claimant a beneficiary of the insurance contract.

Finally, the labored attempt by courts to "find" an implied right of action under unfair claims practices statutes unnecessarily skewed the analysis by redirecting the focus from the grounds for liability to statutory interpretation. After most states concluded that the legislature did not intend for the statutory scheme to include a private right of action, courts were wary of efforts by

113 Id. at 898 .

114 Id. at 901-02. 
claimants to achieve the same result by employing capacious theories of tort liability, such as negligent infliction of emotional distress. This wariness was warranted, because it is a mistake to confuse an injury suffered by a claimant with the ground for liability. Insurers should be held liable not just when they negligently inflict emotional distress, but also when they engage in bad faith claim settlement practices in violation of public policy, resulting in injury to the claimant. Emotional distress may be a common form of injury in these cases, but the injury is not the gravamen of the action. It is conceivable that an insurer could act contrary to public policy and thereby cause financial harm to a claimant for which it should be held liable, even if the claimant does not suffer any emotional distress.

After adjusting the focus from trying to bend traditional causes of action to considering the public policy in issue directly, the question becomes much easier to address. ${ }^{15}$ There can be no argument that there is a strong public policy to promote the fair and timely payment of claims to third-party claimants. Injuries and other forms of loss interrupt economic exchange and potentially shift some of these burdens to extended families, friends, informal organizations such as churches or aid societies, and social relief agencies. The tort-insurance system facilitates a huge redistribution of funds from pooled premiums to injured persons every year. In recognition of the vital importance of this transfer of funds for social and economic reasons, most states have enacted financial responsibility laws which have the practical effect of requiring licensed drivers to carry insurance. Moreover, the practical realities of commercial life require businesses to maintain a program of insurance that provides liability coverage. Insurance quite simply is part of the fabric of life in America.

The insurance industry is heavily regulated to promote the public interest in having insurance proceeds paid as promised. ${ }^{116}$ Insurance premiums are subject to governmental oversight, both to protect the insured from unfair pricing and to promote fiscal solvency. Marketing practices and contract formation are subject to statutory and judicial regulation, as particularly evidenced by the interpretive maxims that construe policies in accordance with the reasonable expectations of the insured. Solvency is directly regulated through reserve requirements, financial oversight, and the establishment of guarantee funds. Finally, of course, states have adopted variations of the Uniform Unfair Claims

115 From a result-oriented perspective, one might argue that it makes more sense to expand traditional doctrines, such as the implied covenant of good faith and fair dealing or the doctrine of third-party intended beneficiary, to address the problem rather than creating a "new" tort. However, it is clear to me that courts simply will not pour this new wine into the old doctrinal vessels. Moreover, although I would not be against creative efforts to break down these doctrinal limitations, I believe that the courts have identified very real conceptual problems in doing so. Consequently, it is my judgment that the best means of holding insurers accountable for their bad faith behavior is to persuade courts to adopt a new approach that raises the merits of the policy questions directly, free from historical doctrinal constraints. Creating a "new" tort will not impress judicial conservatives, but this direct and honest approach might have a chance for success.

116 For a succinct description of the regulation of insurance carriers, see PETER M. LENCSIs, Insurance Regulation in the United states (1997) and Robert H. Jerry II, UnderSTANDING INSURANCE LAW $\$ \$ 22-24$ (2d ed. 1996). 
Practices Act that explicitly require insurers to treat insureds and claimants honestly and fairly.

Indeed, it is obvious that legislatures and courts recognize the important public function of insurance, and have embraced the public policy of maintaining the integrity of the insurance industry by ensuring that promised indemnity payments are made. A common thread in these expressions of public policy is an acknowledgment of the power and sophistication of insurance carriers and a desire to prevent abuse of this power by carriers withholding promised benefits. Translated to the context of third-party claimants, Justice Timlin's dissent in Krupnick succinctly highlights the important public policy implications of allowing the liability insurer to avoid liabilities to claimants, and therefore bears repeating.

It is clear, under our mandatory financial liability laws, as well as under California's Insurance Code, that insurers exist and are allowed to do business in California not only to provide their insureds with financial peace of mind, but to provide persons injured by their insureds with financial recompense for their injuries in a reasonable and good-faith manner.

[p]ublic policy mandates that insurance companies undertake the burden of fairly and timely settling those claims as alleged here, when the insured's liability is reasonably clear and the claimants' damages are reasonably ascertainable and which they have contracted to cover, for a price, rather than allowing such costs and expenses encompassed by the claimed damages to fall on the shoulders of the injured claimants, and, in some cases, on the doctors and hospitals whose bills will go unpaid, the welfare systems to whom the injured parties may be forced to turn, and ultimately on the taxpaying public. ${ }^{117}$

My claim is that Justice Timlin's arguments are better employed to ground liability directly in public policy, rather than using the public policy argument to support tort liability for negligent infliction of emotional distress.

Moving beyond traditional tort and contract doctrine and grounding tort liability expressly in public policy considerations is not unprecedented. I believe that this is precisely what courts did when they created a heightened duty of good faith owed by liability insurers to their insureds, even though courts were not forced to explain the public policy grounds for this cause of action explicitly in light of the general contractual duty of good faith and fair dealing that applied to the relationship between insureds and insurers. ${ }^{118} \mathrm{~A}$

117 Krupnick v. Hartford Accident \& Indem. Co., 34 Cal. Rptr. 2d 39, 85 (Ct. App. 1994) (Timlin, J. dissenting).

118 Recently, the California Supreme Court acknowledged that holding insurers liable for tort damages reflected the policy basis of the cause of action for insurance bad faith. "The availability of tort remedies in the limited context of an insurer's breach of the covenant advances the social policy of safeguarding an insured in an inferior bargaining position who contracts for calamity protection, not commercial advantage." Kransco v. Am. Empire Surplus Lines Ins. Co., 2 P.3d 1, 8 (Cal. 2000) (citing Foley v. Interactive Data Corp., 47 Cal. 3d 654 (1988) (distinguishing the contractual remedies available for breach of the implied duty of good faith and fair dealing in the employment setting from the tort remedies available for insurance bad faith)).

The appellate court expressly relied on the public policy dimensions of the cause of action for insurance bad faith in a recent case upholding the constitutionality of a statute 
better analogy is found in employment law, where the courts have developed the tort of wrongful discharge in violation of public policy. In this dynamic setting, courts have recognized that traditional contract and tort principles are inadequate to protect the public interest, and have responded by expressly imposing tort liability to effectuate public policy.

An employer and employee obviously have a contractual relationship, and also could easily be regarded as having the kind of relationship that might give rise to special tort duties. However, in the absence of an express or implied agreement about the duration of the employment relationship, courts traditionally regard the contractual relationship to be terminable "at will," meaning that either party may end the relationship at any time, for any reason, or for no reason at all. ${ }^{119}$ Moreover, although the contractual relationship gives rise to a duty of good faith and fair dealing, the majority of courts have rejected the insurance law model of importing additional substantive responsibilities into

extending the statute of limitations for certain claims arising out of the Northridge earthquake of 1994. The court summarized:

The field of insurance so greatly affects the public interest that the industry is viewed as a "quasi-public" business, in which the special relationship between the insurers and insureds requires special considerations. "The insurer's obligations are . . rooted in their status as purveyors of a vital service labeled quasi-public in nature. Suppliers of services affected with a public interest must take the public's interest seriously, where necessary placing it before their interest in maximizing gains and limiting disbursements. . . As a supplier of a public service rather than a manufactured product, the obligations of insurers go beyond meeting reasonable expectations of coverage. The obligations of good faith and fair dealing encompass qualities of decency and humanity inherent in the responsibilities of a fiduciary. Insurers hold themselves out as fiduciaries, and with the public's trust must go private responsibility consonant with that trust.'”

The Egan court recognized that the unequal relationship between the insured and insurers demanded special remedies for breach of that public trust, such as tort remedies for the failure to perform obligations promised in a policy and punitive damages. The court explained: "The relationship of insurer and insured is inherently unbalanced; the adhesive nature of insurance contracts places the insurer in a superior bargaining position. The availability of punitive damages is thus compatible with recognition of insurers' underlying public obligations and reflects an attempt to restore balance in the contractual relationship."

The significant public interest in the special relationship between the insured and insurer justifies the availability of tort remedies, and distinguishes insurance contracts from other types of contracts. Tort remedies remain unavailable in non-insurance contract cases. (citations omitted) (emphasis added).

20th Century Ins. Co. v. Superior Court of Los Angeles County, 109 Cal. Rptr. 2d 611, 625 26 (Ct. App. 2001). In a footnote, the court quoted from the Supreme Court opinion in Foley: "Just as the law of contracts fails to provide adequate principles for construing the terms of an insurance policy, the substantial body of law uniquely applicable to insurance contracts is practically irrelevant to commercially oriented contracts. . . These [unique] features characteristic of the insurance contract make it particularly susceptible to public policy considerations." Id. at 626 n.20.

119 For competing histories of the development of the "at will" rule in American, compare Jay M. Fineman, The Development of the Employment at Will Rule, 20 AM. J. LeGAL Hist. 118 (1976) with Deborah A. Ballam, Exploding the Original Myth Regarding Employmentat-Will: The True Origins of the Doctrine, 17 BeRKeley J. EMP \& LAB. L. 19 (1996) and Deborah A. Ballam, The Traditional View on the Origins of the Employment-at-Will Doctrine: Myth or Reality?, 33 Am. Bus. L.J. 1 (1995). 
the contract and regarding breach of this duty as a tort. ${ }^{120}$ Consequently, an employee has no cause of action under common law principles if his employment is terminated suddenly and arbitrarily, despite the obvious fact that the employee suffers injury in these circumstances.

Against the common law backdrop providing that employers have no liability for a "bad faith" or "wrongful" termination, a number of courts have created a tort for wrongful discharge in violation of public policy. ${ }^{121}$ In doing so, courts expressly recognize that employers can abuse their substantial economic power with the threat of termination to induce employees to act contrary to established public policy. The tort grew out of cases that presented particularly egregious facts. In Petermann v. International Brotherhood of Teamsters, Local $396,{ }^{122}$ the court determined that an employee could recover damages when he was fired for refusing to testify falsely at a legislative hearing. The court expressly based its analysis on the strong public policy against perjury. Noting that perjury and the solicitation of perjury were crimes, that court reasoned:

The threat of criminal prosecution would, in many cases, be a sufficient deterrent upon both the employer and employee, the former from soliciting and the latter from committing perjury. However, in order to more fully effectuate the state's declared policy against perjury, the civil law, too, must deny the employer his generally unlimited right to discharge an [at will] employee .... when the reasons for the dismissal is the employee's refusal to commit perjury. . . . The public policy of this state as reflected in the penal code sections referred to above would be seriously impaired if it were to be held that one could be discharged by reason of his refusal to commit perjury. ${ }^{123}$

This analysis quickly was adapted to a variety of contexts, including attempts by employers to discourage employees from pursuing their statutory rights for worker's compensation payments in the absence of a statutory remedy for retaliation. ${ }^{124}$

The emergence of the tort of wrongful discharge in violation of public policy represented a compromise between competing considerations. Courts were unwilling to overrule the longstanding "at will" rule directly by recognizing that an employee who is terminated without just cause should be able to sue in tort or contract for damages. However, courts also were unwilling to permit employers to use their superior economic position under the "at will" regime to influence employee behavior in ways that harmed not just the employee, but the public at large. By creating a tort action that only protects the public interest, and does not protect the employee in situations where the termination of

120 The watershed case is Foley v. Interactive Data Corp., 765 P.2d 373 (Cal. 1988), in which the California Supreme Court explicitly compared the employment relationship to the insurance relationship and determined that the heightened duty of good faith and fair dealing that provided tort remedies in the insurance context should not be extended to the employment context.

121 See generally Mark A. Rothstein, Charles B. Craver, Elinor P. Schroeder \& Elaine W. Shoben, Employment Law $\$ \$ 8.9-8.13$ (2d ed. 1999).

122344 P.2d 25 (Cal. Ct. App. 1959).

123 Id. at 27.

124 The leading case to embrace the Petermann analysis in this setting is Frampton v. Central Indiana Gas Co., 297 N.E.2d 425 (Ind. 1973). 
employment might be unfair to the employee but does not harm the public generally, the courts have fashioned a doctrinal solution that respects both of the competing considerations.

The case law demonstrates that courts have been careful to restrict application of this tort to promoting public policy. Recently, the California Supreme Court held that an employee who alleged that he was constructively discharged because he supported a co-worker's claim of sexual harassment could sue for wrongful discharge in violation of public policy. ${ }^{125}$ The court emphasized the "public" nature of the cause of action and held that employers can be liable only in cases involving a clear constitutional or legislative declaration of fundamental public policy, concluding that:
[a] public policy exception carefully tethered to fundamental policies that are deline- ated in constitutional or statutory provisions strikes the proper balance among the interests of employers, employees and the public. The employer is bound, at a mini- mum, to know the fundamental public policies of the state and nation as expressed in their constitutions and statutes; so limited, the public policy exception presents no impediment to employers that operate within the bounds of law. Employees are pro- tected against employer actions that contravene fundamental state policy. And soci- ety's interests are served through a more stable job market, in which its most important policies are safeguarded. ${ }^{126}$

The court held that the plaintiff stated a cause of action because the employer clearly violated the legislatively enunciated public policy of preventing sexual harassment when it allegedly sought to obstruct an investigation by threatening the employee.

Nowhere in our society is the need greater than in protecting well motivated employees who come forward to testify truthfully in an administrative investigation of charges of discrimination based on sexual harassment. It is self-evident that few employees would cooperate with such investigations if the price were retaliatory discharge from employment. ${ }^{127}$

The court emphasized that the gravamen of the tort action is not that the employee was unfairly fired, but rather that the employee was constructively discharged in a manner that violated important public policies.

The public policy focus of the tort is highlighted by the line of cases that restrict the cause of action to employees who have been discharged (actually or constructively), and denies relief to employees who allege that they have been demoted or otherwise treated unfairly for reasons that violate public policy. Although the employee certainly suffers if she is demoted for an illegitimate reason, the more subtle factual ambiguities presented in "wrongful demotion" or "wrongful failure to hire" cases lead the majority of courts to conclude that the public interest in preserving the managerial discretion of the at will rule trumps the public interest in protecting employees who are discharged for reasons that violate public policy. ${ }^{128}$ In addition, there are an abundance of cases

125 Gantt v. Sentry Ins., 824 P.2d 680 (Cal. 1992), rev'd on other grounds, Green v. Ralee Eng'g Co., 960 P.2d 1046 (Cal. 1998).

126 Id. at $687-88$.

127 Id. at 689.

128 See, e.g., White v. State, 929 P.2d 396 (Wash. 1997); Mintz v. Bell Atl. Sys. Leasing Int'l, Inc., 905 P.2d 559 (Ariz. Ct. App. 1995); Zimmerman v. Buchheit of Sparta Inc., 645 N.E.2d 877 (Ill. 1994). But see Brigham v. Dillon Cos., Inc., 935 P.2d 1054 (Kan. 1997); 
in which employees have been fired for what appear to be callous, if not malicious, reasons, but the courts hold that the employee may not recover damages because the employer's conduct does not sufficiently implicate public policy. ${ }^{29}$

The tort of wrongful discharge in violation of public policy provides a good model for imposing liability on insurance carriers when they deal with third-party claimants in bad faith. Third-party claimants are not owed contractual or tort duties directly, just as at will employees are not owed duties regarding the duration of their employment, but nevertheless an insurance carrier can act in a manner that not only injures the claimant but also frustrates important public policies. Courts should recognize the tort of bad faith settlement practices in violation of public policy, even if they choose not to reconsider the baseline common law rule that a liability carrier owes no duties to a third-party claimant.

I would not be adverse to a judicial declaration that the baseline common law rule has outlived its usefulness, but this is highly unlikely in light of the unanimous and continuing support for that rule. ${ }^{130}$ In the context of employment law, one author has argued that the tort of wrongful discharge in violation of public policy is part of an elaborate judicial dance around the real issue: overruling the at will rule and recognizing a cause of action for termination of employment without just cause. ${ }^{131}$ However, courts are not ready to take the next step and declare that unjust terminations in themselves violate public policy. One of the first wrongful discharge cases opened this possibility, but courts have not taken this path. ${ }^{132}$ Just as the courts have embraced the public

Michael D. Moberly \& Carolann E. Doran, The Nose of the Camel: Extending the Public Policy Exception Beyond the Wrongful Discharge Context, 13 LAB. LAw. 371 (1997).

129 In Illinois, for example, although the supreme court wholeheartedly embraced the tort of wrongful discharge in violation of public policy, see Palmateer v. Int'l Harvester Co., 421 N.E.2d 876 (Ill. 1981), courts subsequently have narrowed the circumstances in which the employer is deemed to have violated a clearly mandated public policy. See, e.g., Price v. Carmack Datsun, Inc., 485 N.E.2d 359 (IIl. 1985) (employee alleging that he was fired for filing a claim under the employer-sponsored health insurance plan raised merely a personal claim); Pratt v. Caterpillar Tractor Co., 500 N.E.2d 1001 (Ill. App. Ct. 1986) (employee alleging that he was terminated for refusing to violate a federal anti-kickback statute did not implicate the public policy of Illinois); McCluskey v. Clark Oil \& Refining Corp., 498 N.E.2d 559 (Ill. App. Ct. 1986) (employee alleging that she was terminated solely for marrying a co-worker did not state a cause of action for wrongful discharge in violation of public policy in the absence of demonstrating that the employer's action significantly interfered with the fundamental right to decide to marry). These cases demonstrate the emphasis that courts place on finding a strong nexus with public policy rather than undermining the at will rule by according rights to individual employees when they are discharged without just cause. This is not to say that the contours of "public policy" are self-evident. For example, a growing number of courts recognize that an employer's abuse of power regarding a violation of federal, as opposed to state, law triggers the public policy interests of the state. See, e.g., Faulkner v. United Techs. Corp., 693 A.2d 293 (Conn. 1997); Tameny v. Atl. Richfield Co., 610 P.2d 1330 (Cal. 1980).

130 See supra note 113.

131 Comielius J. Peck, Penetrating Doctrinal Camouflage: Understanding the Development of the Law of Wrongful Discharge, 66 WASH. L. REv. 719 (1991).

132 See Monge v. Beebe Rubber Co., 316 A.2d 549 (N.H. 1974) (holding that the public interest warrants holding employers liable for terminating employment in bad faith, with malice, or in retaliation). 
policy tort of wrongful discharge as an acceptable, intermediate doctrinal step in employment law, I believe that courts could embrace the public policy tort of bad faith settlement practices as an acceptable, intermediate step in insurance law.

The public policy analysis under this new cause of action will raise as many difficult interpretive and policy issues as any other common law action, but it poses no unique or insuperable difficulties. Courts should have little difficulty identifying the core public policies at stake in these cases. Unlike Royal Globe, which sought to find a cause of action in the Unfair Claim Practices Act as a matter of statutory interpretation, courts would begin by regarding the state insurance code as legislative pronouncement of public policy. Additionally, statutes and regulations regarding deceptive business conduct or deceptive advertising would reaffirm the legislature's identification of public policies. Using the common law method of reasoned elaboration, courts would carefully assess a claimant's allegations and determine if the interests at stake were primarily personal, or whether they involve important questions of public policy.

The insurance industry will argue forcefully that this new cause of action will raise the price of liability insurance and perhaps even restrict its availability in some markets or jurisdictions. The threat that every claim settlement process will result in the injured party returning to the trough with a cobbled together theory of bad faith that can survive dismissal should not be lightly disregarded. If recognizing insurer liability would lead to large numbers of cases being filed, all of which have at least "nuisance settlement value," then the financial implications for insurers would be substantial. This poses a combination of empirical and normative issues that are summarized by a deceptively simple question: Would recognition of the cause of action lead to higher costs and inefficiencies to such a degree that important public policies would be frustrated more than they would be advanced?

The nature of the liability goes a long way in providing some assurance that the insurer's fears are unwarranted. Because the gravamen of the action is the public interest rather than the personal interest of the claimant, the fact that the claimant has a plausible claim of injury will not lead to an immediate settlement value for the case. Again returning to the example of wrongful discharge law as a guide, plaintiffs' lawyers have found it difficult to make out claims of wrongful discharge in violation of public policy even when their client has been poorly treated and suffered substantial losses. The appellate courts have carefully enforced the public policy requirement precisely to ensure that the cause of action does not interfere unduly with the public policy favoring managerial flexibility. Securing appellate court decisions absolving them of liability does not come cheap for employers, but in my experience most of these cases at the appellate level involve employees who have been treated unfairly in some way. Consequently, the situation today is that parties who have been wronged in some way are unsuccessfully seeking to come within the scope of a relatively restrictive cause of action. If the cost of this litigation promotes better treat- 
ment of employees not covered by the limited cause of action, there is not necessarily a loss from the perspective of the public interest. ${ }^{133}$

There is no reason to expect that the experience in the insurance context will be any different. If the collateral cost of recognizing the tort of bad faith settlement practices is that third-party claimants who have been poorly treated by insurers bring suits that can be dismissed only after expensive proceedings establish that there is no public policy nexus, it is difficult to conclude that this cost is "wasted." Plaintiff's lawyers will quickly learn that the cause of action is not made simply by showing injury to their client, and so even unsuccessful cases typically will involve plausible claims both that the claimant has suffered a loss, and that the insurer acted in a manner contrary to public policy. Unlike the employment law setting where wrongful discharge can be inserted in a complaint as one cause of action among many, the typical third-party claimant will be able to assert only this single cause of action, although there may be claims sounding in infliction of emotional distress and fraud as well. With bad faith claims practices in violation of public policy being the only plausible hope for recovery, plaintiffs' lawyers are unlikely to take many long-shot cases on a contingency fee basis.

There is always the threat that completely unfounded claims will be brought by aggressive attorneys hoping against the odds to add a windfall to the underlying tort verdict or settlement. But unless there is some reason to believe that fraudulent behavior will be more prevalent in the insurance setting, the same argument would hold true for every cause of action. There certainly are people who feign substantial injuries in slip and fall cases in order to milk the system, but it does not follow that we should no longer hold property owners liable for injuries because there is such fraud. The problem of "holdup" litigation is just not unique to the liability insurance setting.

Notwithstanding all of the foregoing, the public policy nature of this cause of action suggests that the courts should develop rules and guidelines that mediate the competing values at stake. Perhaps the most important step would be for courts to preclude recovery of punitive damages by third-party claimants. The specter of the $\$ 15,000$ auto accident case turning into a multi-million dollar punitive damages award for unfair claim practices surely would loom large in insurers' minds. To the extent there is no indication that the "lottery" of punitive damages would incrementally deter bad faith behavior sufficiently to justify this potentially counter-productive incentive for claimants and their lawyers, punitive damages would not be justified. This limitation of damages would easily be justified on principled grounds because the Insurance Code of every state establishes an administrative mechanism to identify and sanction unfair claim practices in the event that the insurer's behavior is part of a pattern of egregious behavior. With this administrative remedy in the background, and with the likelihood that many successful cases will include consequential damages and damages for emotional distress injuries, it can easily be argued that

133 Should we really be too concerned about the increase of litigation that occurs when an employee who has been fired solely because she married a co-worker has the temerity to assert that this exercise of managerial power is in violation of important public policies? See supra note 127. 
the public policy tort of bad faith settlement practices should not allow for punitive damages of any kind.

Additionally, it may be prudent to employ a variation of the burden shifting device used by courts in Title VII cases. ${ }^{134}$ A third-party claimant would be required to plead and prove that (1) she made a legitimate claim against the insured and provided sufficient documentation and other evidence to support the claim, (2) she ultimately received payment on the claim either by court judgment or settlement, and (3) that this payment was delayed or was below the value of the claim, or both. Having established this prima facie case, the burden of production would shift to the insurer to demonstrate how it valued the claim and conducted the settlement or litigation of the claim. At this stage, the court should engage in the presumption that the insurer did not act in bad faith. Finally, the ultimate burden of proof would shift back to the claimant to demonstrate that the insurer's defense of its actions are pre-textual in some manner, and that the insurer in fact refused to pay a legitimate claim honestly and fairly in an effort to maximize its own profits by taking advantage of the claimant's situation. This burden-shifting approach would mean that bad faith claims practices cases would not be easy to win, but in cases of true bad faith rising to the level of a violation of public policy there still would be a reasonable chance for the claimant to prevail and recover substantial damages.

Admittedly, many details and considerations have not been considered in this essay. Rather than concluding this essay with a foolish attempt to delineate in advance even greater details of case law not yet decided, in the spirit of the Symposium I have included an Appendix that provides my suggestion of how a judicial opinion might read if the court decided to commence this line of analysis. If my hypothetical opinion ever were to be adopted by a court, it certainly would be my favorite insurance law case.

134 See McDonnell Douglas Corp. v. Green, 411 U.S. 792 (1973); Tex. Dep't. Of Cmty. Affairs v. Burdine, 450 U.S. 248 (1981); St. Mary's Honor Ctr. v. Hicks, 509 U.S. 502 (1993). 


\title{
Appendix: My Favorite Insurance Case
}

\author{
Ben A. Patsy, et. al. v. Family Insurance Bureau \\ Supreme Court of Penn State
}

DeCEMBER 1, 2001

MOOTZ, J.

\section{All Justices concurred.}

The plaintiffs, Ben. A. Patsy, Ima Patsy, and their minor children, sued Family Insurance Bureau (FIB), alleging that they suffered economic harm and emotional distress as a result of FIB's conduct in settling a claim brought by the Patsies against FIB's insured. The Patsies were rear-ended by the insured and suffered substantial personal injuries and property damage to their vehicle. In a one-count complaint, the Patsies allege that FIB knew its insured was liable for the accident and that they had suffered substantial losses, but that it nevertheless refused to settle the claim filed by the Patsies for more than two years. They alleged further that FIB interposed groundless defenses and stalled the negotiations and litigation solely for the purpose of inducing a lower settlement. The Patsies contend that FIB took advantage of increasing economic, psychological, and emotional pressures they experienced due to the fact that their losses were uncompensated for several years despite the clear liability of FIB's insured.

Discovery has brought to light a calculated and comprehensive scheme by FIB to avoid paying the legitimate value of claims, ${ }^{135}$ For over two decades FIB set monthly caps on liability payments, and rewarded claims adjusters who paid less than the market value for claims. Agents lied to their insureds about the litigation, changed the contents of the claims files without any factual basis to provide a pretextual basis for refusing to settle cases, and particularly directed its fraudulent practices toward those persons - including the poor, uneducated, and elderly - that FIB believed would be less likely to object or to take legal action to pursue their rights. In furtherance of this scheme, FIB systematically harassed and intimidated claimants, their attorneys, and witnesses. One document evidenced FIB's corporate policy of employing "mad dog defense tactics" by using its sophistication and resources to overwhelm claimants' attorneys by delaying litigation proceedings, making legal arguments and objections that had no merit, destroying documents, and abusing the civil trial process. Another document evidenced a "bonus" system for FIB's staff attorneys that awarded money, trips to Disney World, and trophies to attorneys who litigated cases aggressively. ${ }^{136}$

135 These facts may appear far-fetched, but I am closely tracking (and to some extent directly quoting) the summary of facts in a recent first-party bad faith case. See Campbell v. State Farm Mut. Auto. Ins. Co., 2001 WL 1246676, at *9-10 (Utah Oct. 19, 2001) (reinstating a punitive damages award of $\$ 145$ million against State Farm for its "reprehensible conduct," after the trial court had ordered remittitur to $\$ 25$ million in punitive damages). 136 This frightening detail is drawn from the allegations in Crackel v. Allstate Insurance Co. See Porter, supra note 33 in main text. 
The Patsies seek the following damages: the difference between the value of their injuries and the amount that they were forced to accept in settlement, the collateral financial injury proximately caused because they did not receive fair compensation within a reasonable time of the accident, damages for the emotional distress caused by mounting financial pressures, attorneys fees incurred due to the delay, and punitive damages. The trial court entered summary judgment for FIB, reasoning that FIB owed no duty - whether contractual, tort, or statutory - to the Patsies, and therefore could not be held liable for its conduct in settling the Patsies' claims against its insured.

We reverse and remand. We direct the trial court to reinstate the Patsies' cause of action and to conduct further proceedings in accordance with this decision.

The trial court correctly stated that we consistently have held that liability insurers owe no duties to third-party claimants, since insurers stand in the shoes of their insureds and therefore are in an adversarial relationship with claimants. Although in 1979 this court implied a private cause of action under the Unfair Claims Practices Act, we subsequently concluded that the statute could not bear this construction. A few claimants have prevailed under theories of fraud or intentional infliction of emotional distress, but these theories reach only the most egregious cases of insurer bad faith. We recently rejected a claimant's attempt to use the recently expanded tort of negligent infliction of emotional distress to recover for bad faith conduct in the settlement process, signaling that we would not twist this tort to serve as a replacement for the implied statutory cause of action. In light of this doctrinal history, the trial court concluded that the Patsies failed to state a claim for which relief can be granted.

Today, we hold that important considerations of public policy require insurers to bear the costs of their bad faith practices in settling claims. We choose not to shoehorn insurer liability into preexisting tort or contract doctrine, inasmuch as general torts such as negligent infliction of emotional distress do not comprehensively address the nature of the wrong against the public in this setting. We do not mean to suggest that insurers are insulated from liability under traditional tort and contract principles. If an insurer acts toward a third-party claimant in a manner that gives rise to a cause of action sounding in negligent infliction of emotional distress, then the insurer will be held accountable for its tortious behavior. However, traditional contract and tort theories are not sufficient to vindicate the important public policies at issue in these cases.

We regard our action today as wholly consistent with the common law process. Duties giving rise to tort liability are not etched in the heavens, awaiting our apprehension of their timeless dictates. Rather, tort duties are imposed in order to recognize important social interests in a (sometimes rapidly) changing economic, political, and social context. Traditional tort doctrine is inadequate to protect the public interest in the liability insurance context because such doctrines can be both over-inclusive (by expanding liability too far and introducing uncertainty and needless litigation) and under-inclusive (by failing to protect the public interests fully). Consequently, we now hold that insurers owe a duty to third-party claimants such as the Patsies not to engage in bad faith settlement practices that violate public policy. 
We are not breaking entirely new ground with this decision. In the analogous setting of employment law, we have created a cause of action sounding in tort on behalf of "at will" employees who are terminated in violation of established public policy, even in circumstances where the employee could assert no claim for breach of contract or breach of a duty under general tort principles. In these cases, we recognized that the public interest is advanced by subjecting employers to tort damages when they use their superior economic power and greater sophistication in an attempt to compel actions or forbearances by their employees that injure the public. For example, when an employee alleged that she was given an ultimatum either to work in an unsafe workplace or to be fired, we held that the strong and pronounced public policy that employers must maintain a safe workplace justified holding the employer liable in tort for attempting to use its unmatched power to terminate an employee as a tool for thwarting this important public policy.

We hold that liability insurers are liable in tort if they act in bad faith when handling a claim by a third party. Insurers act in bad faith if they seek to avoid obligations of their insured that cannot be contested honestly and legitimately, for the purpose of using their superior negotiating position to pressure the third party into accepting an inadequate settlement rather than spending the time and resources necessary to obtain a judgment against the insured. This bad faith conduct might best be characterized as a form of "reverse insurance fraud," in which the insurance carrier seeks to pay less than the legitimate value of the claim, even though its state-approved premiums are premised on paying the full value of claims. Under our decision, there will be no liability if an insurer investigates the claim and then challenges the third party's allegations of liability or claim of damages in good faith, even if the verdict obtained by the claimant ultimately vindicates her position. The bad faith conduct that is injurious to the public is the insurer's use of specious and pretextual arguments to avoid settlement and its use of delay in payment to exert pressure on the claimant to accept less than the claimant could reasonably expect to receive for her injuries.

Because a liability insurer steps into the shoes of the tortfeasor in order to resolve a claim asserted by a third party, there is an adversarial relationship between the insurer and the third-party claimant. Nothing in our opinion today requires insurers to place the interests of the claimant above the interests of their insured. If an accident leaves a claimant with losses of approximately $\$ 2000-\$ 5000$, but the claimant makes a demand for the policy limit of $\$ 50,000$, the insurer is entirely justified in rejecting the offer and pushing the matter to trial. The delay in payment in such a case is occasioned by the claimant's unreasonable demands, rather than the insurer's bad faith conduct. On the other hand, if an accident where liability is clear leaves a claimant with losses of approximately $\$ 10,000-\$ 15,000$, it will almost certainly be bad faith for the insurer to refuse to offer more than $\$ 2000$ to settle the matter. In this case, the insurer would not be vindicating its insured's rights, but rather would be seeking to improve its own profitability by refusing to pay the fair value of claims that it has agreed to pay on behalf of its insured.

We do not attempt to hold insurers to a detailed affirmative standard of good faith insurance practices, since that would more properly be the subject of 
legislative and regulatory action. Moreover, the varieties of factual scenarios in which the insurer might act in bad faith under the principles announced in this decision prevent us from specifying in detail the conduct that will give rise to liability. This is not unusual in tort law, of course, as the general standard of negligence is creatively adapted to endless factual scenarios. Nevertheless, as with general negligence, we believe that over time courts will identify certain conduct that almost always constitutes actionable bad faith. Such conduct might include: interposing defenses that the insurer knows are factually groundless, seeking to delay settlement negotiations or litigation solely for the purpose of capitalizing on financial or emotional pressures that the claimant is experiencing as a result of the loss in question, and using deceptive tactics designed to obtain an unreasonably low settlement because the claimant does not understand her rights, such as by providing an immediate payment for only part of the loss in exchange for the claimant unknowingly executing a general release. As with all common law causes of action, the contours of the tort of bad faith claim settlement practices will evolve on a case-by-case basis and remain sensitive to social, economic, and business developments.

We regard the public interests at stake to be sufficiently important to recognize this new cause of action against liability insurers. The legislature has enacted a detailed insurance code designed to protect the public, and almost from the inception of the insurance industry there has been substantial governmental oversight to protect the public from harm. In particular, of course, the legislature has enacted a detailed statute proscribing certain unfair practices in the settlement of claims, and the Insurance Commissioner is empowered to levy fines to punish this behavior. In addition, the legislature has acknowledged the public importance of insurance by enacting financial responsibility laws for those who drive automobiles. Finally, there is a consistent theme in this court's insurance jurisprudence that compensating injured third parties is one of the important determinants in how we construe the insurance relationship. There can be no doubt that there is a strong public interest in the efficient and fair settlement of claims made against insurers by injured third parties.

This public interest is not necessarily co-extensive with the personal interests of the third-party claimant. The claimant's only interest is to obtain the maximum payment as quickly as possible. However, the public interest is best served when insurers act reasonably and fairly, which will not always result in immediate payments of claims. Inflated claims and insurance fraud harm the public interest by increasing the cost of insurance, and insurers should be encouraged to protect against this behavior. Public policy requires insurers to pay claims only when liability has been reasonably established by a timely investigation, and only to the extent of the fair and reasonable value of the losses. Additionally, public policy requires that insurers deal with claimants fairly and honestly, but does not justify imposing fiduciary obligations on insurers in these dealings. Consequently, there will be many instances in which a claimant is dissatisfied with the handling of the claim, but nevertheless the insurer will not have acted in a manner that violates public policy.

We emphasize that liability for bad faith insurance settlement practices in violation of public policy is conceptually and factually distinct from an insurer's liability to its insured for bad faith refusal to settle within policy lim- 
its. Because it has complete control over the litigation, an insurer can expose its insured to an excess verdict by refusing to settle within the policy limit. In recognition of the inherent conflict of interest, even if the insurer honestly believes that the verdict will be within the policy limit, we do not permit it to gamble with the insured's money when there is a substantial possibility that the gamble will not pay off. Under well-established principles, we insulate the insured from any financial loss in these circumstances by requiring the insurer to pay the full verdict. In contrast, a refusal to settle within policy limits does not necessarily harm the public interest in a manner that justifies holding the insurer liable to a third-party claimant. For example, if the insurer honestly and reasonably rejects the claimant's demand for the policy limit as unsupported by the facts, the insurer has breached no duty to the third-party claimant even in the event of an excess verdict. On the other hand, if the insurer refuses to settle within policy limits when liability and damages are reasonably clear, stonewalling the third-party claimant into protracted discovery and a full trial, the insurer has breached its duty to the claimant regardless of whether there is an excess verdict. Payment of the verdict does not fully compensate the claimant, even when the excess verdict is fully funded by the insurer due to its liability to its insured for bad faith. In this situation, the claimant is entitled to recover consequential damages caused by the delay in settlement, including damages for emotional distress. The third-party claimant very well might suffer substantial consequential financial losses if its legitimate claim remains unpaid for years. It is these collateral losses, in large part, that implicate the public interest.

We are mindful that our decision today might be regarded as an invitation for frivolous litigation by claimants seeking to supplement their settlement or verdict with additional funds from the insurer. We emphasize that the public policy ground for liability restricts the scope of this tort remedy only to conduct that harms the public interest. Delay in paying a claim, in itself, is not actionable, even if the delay injures the claimant. The public interest is implicated only when the delay in payment occurs despite reasonably clear liability resulting in damages that can be calculated with reasonable certainty. Bad faith settlement of an insurance claim in violation of public policy is not necessarily an intentional tort, since it is plausible that gross or reckless indifference to the interests of the claimant could implicate public policy, but liability clearly requires more than inadvertent negligence caused by honest mix-ups or even incompetence that delays processing a claim. Determining whether the insurer is culpable presents a question of fact for the trier, but we fully expect that the courts will ensure that only cases with potential merit will survive dismissal and summary judgment.

Turning to the facts presented in this case, we reverse the trial court's dismissal of the action. The plaintiffs have expressly pleaded that the defendant knew its insured was liable and the value of the loss, but nevertheless persisted in delay and obfuscation for the purpose of inducing a low settlement. Such conduct, if proved at trial, is injurious to the well-established public policy of this state and gives rise to liability. The plaintiffs have alleged that they suffered financial loss, emotional distress, and increased attorneys' fees. The 
plaintiffs may be compensated for these items of damages, subject to sufficient proof at trial.

The plaintiffs also seek punitive damages, but we hold as a matter of law that punitive damages cannot be awarded in this action. There can be no doubt that the allegations against FIB concern reprehensible and malicious behavior that cannot be tolerated. Nevertheless, we are hesitant to permit punitive damages for the tort action that we recognize today. First, we acknowledge that FIB could have reasonably believed under previous case law that its extreme behavior would not give rise to any manner of liability to the Patsies. We decline to permit an award of punitive damages in the case that announces a change in previous law to recognize liability. Moreover, the regulatory regime established by the Unfair Claims Practices Act represents the legislature's determination of when it is appropriate for the Commissioner of Insurance to sanction insurer wrongdoing. In light of this regulatory mechanism for imposing punishment, we restrict plaintiffs to compensation for their losses when they bring suit for bad faith insurance settlement practices in violation of public policy, reserving our authority to revisit this limitation on damages if it appears that administrative enforcement is not advancing the public interest and in the absence of a clear legislative determination that the Commissioner has the sole authority to award such damages.

Reversed and remanded, with direction. 